\title{
Income Changes and Consumption: Evidence from the 2013 Federal Government Shutdown *
}

\author{
Scott R. Baker ${ }^{\dagger} \quad$ Constantine Yannelis ${ }^{\ddagger}$
}

February 2015

\section{PRELIMINARY AND INCOMPLETE - NOT FOR CIRCULATION OR CITATION}

\begin{abstract}
We use the 2013 federal government shutdown and rich data set from an online personal finance website to study the effects of changes in income on changes in consumption. The 2013 shutdown represented a significant and unanticipated income shock for federal government workers, with no direct effect on permanent income. We exploit both the differences between unaffected state employees and affected federal employees as well as between federal employees required to remain at work and those required to stay at home. Furthermore, we are able to discern various detailed types of household spending with widely varying elasticities. We find strong evidence for excess sensitivity of consumption patterns, violating the permanent income hypothesis. We demonstrate that this decline in spending can be largely explained by credit constraints, increased home production, and changes in time allocation. The results demonstrate the importance of liquidity and behavioral responses when constructing stimulus or social insurance policy.
\end{abstract}

\footnotetext{
*The authors wish to thank Nick Bloom, Caroline Hoxby, Petra Persson, and Luigi Pistaferri for helpful comments and suggestions, as well as seminar and conference participants at the All California Labor Conference at UC Berkeley, Kellogg School of Management, and Stanford University. Constantine Yannelis is grateful to the Alexander S. Onassis Foundation for funding and support.

${ }^{\dagger}$ Department of Finance, Kellogg School of Management, 2169 Campus Dr, Evanston, IL $60208 . \quad$ sbaker@kellogg.northwestern.edu

${ }^{\ddagger}$ Department of Economics, Stanford University, 579 Serra Mall, Stanford, CA 94305-6072. yannelis@ stanford.edu
} 


\section{Introduction}

\subsection{The 2013 US Government Shutdown}

At the beginning of the 2013 fiscal year, and following the inability of politicians to agree on a spending plan that included funding for the Patient Protection and Affordable Care Act, the US federal government ceased most non-essential operations. This shutdown lasted between October 1 and 16, 2013, representing the second longest since 1980 and the largest measured by employee furlough days. Table 1 provides an overview of the events leading up to and during the shutdown, and Burwell (2013) provides an official overview of the impact of the shutdown. During the shutdown, the majority of civilian federal government employees were not paid. ${ }^{1}$ Following the conclusion of the shutdown, employees received all of their foregone pay, totaling approximately $\$ 2$ billion. Most federal government workers received their back-pay either in the second pay period at the end of October, between October 25 and November 1 or during the final months of 2013. Thus, the operational effect for most affected employees was a cut in pay of approximately $40 \%$ during the first pay period in October and then an increase in pay of approximately $40 \%$ during the second pay period in October. ${ }^{2}$ There was no change in permanent income, only a temporary income reallocation during the month of October in 2013 for federal employees.

Workers who were affected by the shutdown (in terms of cuts in pay) were divided into two groups. Excepted employees were required to work without pay during the shutdown, as the nature of their work was deemed essential to national security, public health or safety. Other workers deemed non-essential were furloughed and kept off the job while the shutdown was in effect. Both groups experienced only a temporary income shock as they were given all of their foregone earnings following the conclusion of the shutdown. There was significant between agency variation in the rate of employees who were excepted or furloughed. For example, employees at the Departments of Veteran Affairs, Justice and Homeland Security were deemed essential to national security, and more than three quarters were excepted. During the same time period approximately $95 \%$ of employees at the Department of Education, Department of Housing and Urban Development, the Environmental Protection Agency, and the Securities and Ex-

\footnotetext{
${ }^{1}$ Some agencies such as the US Postal Service, Federal Courts, the State Department, and uniformed military personnel are primarily self funded or funded through special appropriations bills that are not part of the normal budgetary process. Employees of these agencies were deemed exempt and were paid during the shutdown.

${ }^{2}$ The first payday in October was October 11th for most federal employees, covering the dates of September 22nd to October 5th. Affected employees received checks on October 11th that paid them for work done in September but not for any work done on or after October 1st. For full time employees, this would represent pay for 6 days of work rather than the usual 10 days.
} 
change Commission were deemed non-essential and furloughed. For a list of agencies affected by the shutdown see table 2 .

The between-agency variation in furloughs is one reason for a wedge in household spending responses to the temporary income declines. While exempted workers were required to continue working, furloughed workers were able to forgo work-related expenses like commuting and could increase home production activities like cooking or performing their own housework. Much work has focused on this area, finding significant declines in actual expenditures among the unemployed and retirees but smaller declines in proxies for consumption or utility. ${ }^{3}$

The 2013 government shutdown, combined with detailed household financial data, provides a number of key advantages for studying the effects of changes in income on consumption. First, the shutdown had no effect on permanent income, meaning that the canonical permanent income hypothesis predicts a precise null hypothesis of zero effect on household consumption. Second, differences in excepted and furloughed workers allow us to separately examine the home production and leisure margins. Finally, data on financial accounts and credit limits gives us the ability to measure to what degree credit and liquidity constraints drove the observed consumption effects.

\subsection{Mechanics of Delayed Pay}

Federal employees were affected to varying degrees by the government shutdown due to different pay period calendars at government agencies. For instance, many employees received pay at monthly increments, meaning their pay generally came at the start or end of each month. This pay would be unaffected by the government shutdown because by the time their payday for October arrived (either on the 31st of October or the 1st of November), the shutdown had ended and they were able to receive their full pay. In this paper, we generally count these employees as being unaffected by the shutdown.

Many other federal employees are on pay period calendars that had them receive bi-weekly checks on October 11th and 25th. These pay periods covered September 22nd-October 5th and October 6thOctober 19th. The first of these paychecks would see an approximate decline in pay of about $40 \%$ (they received pay only for the 6 days worked in September and none of the days worked in October). For the paycheck on the 25th, with the shutdown ended, employees would receive their normal paycheck as well as back pay for the workdays missing from their previous paycheck. The end result in this example

\footnotetext{
${ }^{3}$ See Jappelli and Pistaferri (2010) for a thorough survey.
} 
would be $40 \%$ lower pay for their first paycheck of October and $40 \%$ higher pay on their second October paycheck. Other variations of this pattern occurred for employees across differing pay period calendars, but few employees missed an entire paycheck due to how pay periods lined up with the shutdown.

\subsection{The Sensitivity of Consumption to Changes in Income}

Our analysis sample includes about 150,000 state and federal government employees in 2013. In our main specification, we estimate the following equations

$$
\begin{gathered}
y_{i t}=\alpha_{t}+\alpha_{i}+\sum_{i=1}^{T} \gamma_{i} \mathbb{1}\{i=t\}_{t} \times \mathbb{1}\{G o v\}_{i}+\beta X_{i t}+\varepsilon_{i t} \\
c_{i t}=\eta_{t}+\eta_{i}+\sum_{i=1}^{T} \tau_{i} \mathbb{1}\{i=t\}_{t} \times \mathbb{1}\{G o v\}_{i}+\zeta X_{i t}+\xi_{i t}
\end{gathered}
$$

where $y_{i t}$ is income or log income, $c_{i t}$ is spending or log spending and $X_{i t}$ are demographic and other controls for individual $i$ in time period $t$. Our coefficients of interest are the interactions between $\mathbb{1}\{G o v\}_{i}$, and indicator of whether not an individual works for a federal government agency that was affected by the shutdown and $\mathbb{1}\{i=t\}_{t}$, a time period gummy. Let the subscript $s$ denote time periods when the government shutdown was in effect. We also include two week time period fixed effects $\alpha_{t}$ to capture factors such as seasonality and time varying economic conditions, as well as individual or agency week fixed effects $\alpha_{i}$ to capture unobserved time invariant differences between workers and agencies.

The ratio of the coefficients $\frac{\tau_{s}}{\gamma_{s}}$ provides us with an estimate of the sensitivity of consumption to changes in income, where $s$ denotes a period in which the shutdown is in effect. Estimated in levels, the ratio can be interpreted as a marginal propensity to consume (MPC). We will estimate analogous specifications of 1 and 2, replacing the dependent variable with logarithms of income and spending to estimate the elasticity of consumption with respect to income. In a world in which the permanent income hypothesis is valid, and agents are able to borrow and save freely, the MPC resulting from a transitory income shock should be close to zero. If individuals are credit constrained, the MPC can be as large as one.

A large literature has found there there is excess sensitivity of consumption to changes in consumption, which violates the canonical permanent income hypothesis. See Jappelli and Pistaferri (2010) for a review of the literature. The nature of the 2013 US government shutdown allows us to go be- 
yond testing for excess sensitivity, and use between agency variation to separate the effects of credit constraints and home production or leisure. We can add an interaction term for furloughed workers, $\mathbb{1}\{i=t\}_{t} \times \mathbb{1}\{\text { Gov }\}_{i} \times \mathbb{1}\left\{\right.$ Furlough $_{i}$, to equations 1 and 2 . The coefficient on the interaction terms gives the additional drop in consumption for furloughed workers, who were subject to both the a transitory loss of income and increased leisure time or possible home production due to being sent home during the shutdown.

\subsection{Was the Shutdown Anticipated?}

One important consideration is the extent to which the government shutdown was anticipated by households. Theory predicts that unanticipated and anticipated changes in income will have very different impacts on consumption. The permanent income hypothesis predicts that anticipated transitory income shocks should not have an effect on consumption, as individuals will save to smooth consumption. The institutional framework of the 2013 government shutdown does not provide a clear answer to the question of whether or not the shutdown was anticipated. While it was known that the federal government would shutdown if a continuing resolution was not passed, it is possible that many workers predicted that a last minute deal would be reached as occurred several times in debt ceiling negotiations.

We claim that the shutdown was largely unanticipated; despite high levels of polarization and political uncertainty, there was no clear indication that the shutdown would actually occur. Several similar standoffs led to last minute continuing resolutions that kept the government running. In addition, other research often shows a lack of attention or understanding of economic news. Eggers and Fouirnaies (2014) find that households strongly respond to the media announcing that the economy is in a recession, leading to the conclusion that these households pay little attention to economic fundamentals and only respond to the additional media attention. Figure 3 provides suggestive evidence that the shutdown was not anticipated. The left panel displays the daily number of newspaper articles written that mention the phrase "government shutdown" as a fraction of all newspaper articles from June 1st, 2013 to February 28th, 2014. Articles are queried using the Access World News Newsbank database which is composed of almost 2000 newspapers in 2014. ${ }^{4}$ This graph indicates the dramatic surge in media attention paid to the government shutdown which did not significantly precede the shutdown itself.

The right panel of Figure 3 focuses on the 3 weeks immediately preceding the government shutdown.

\footnotetext{
${ }^{4}$ News query was run on June 15,2014
} 
In blue is again the fraction of newspaper articles written that mention the shutdown. In red is the probability of the shutdown occurring as calculated by the betting market website Inkling Markets. The two series are highly correlated, with both series only seeing significant increases in the 7 days leading up to the shutdown. This suggests that there was not a great deal of anticipation by either the media or prediction market participants, who have been shown to be fairly accurate predictors of political outcomes. $^{5}$ Thus, it is unlikely that affected federal employees were able to significantly alter their consumption and savings behavior in the short period before the shutdown began and their income was disrupted.

We empirically test this using the following specification:

$$
s_{i t}=\delta_{t}+\delta_{i}+\sum_{i=1}^{T} \rho_{i} \mathbb{1}\{i=t\}_{t} \times \mathbb{1}\{G o v\}_{i}+\kappa X_{i t}+e_{i t}
$$

where $s_{i t}$ is the amount individual $i$ saved in period $t$. A test for whether or not the shutdown was anticipated is $\rho_{i}=0$ for all $i=p$ where $p$ denotes the three months before the shutdown. The intuition behind this test is that if federal government workers could have anticipated the shutdown, they would have saved to smooth consumption. We collapse the data to the monthly level and find no significant change in behavior in the days/weeks leading up to the shutdown. We find that, if anything, federal government workers save less than state government workers in the months preceding the shutdown although the difference is not significantly different from zero at conventional levels. This confirms the evidence from newspaper articles and prediction markets, namely that the shutdown was not anticipated.

\section{Data}

The data used in this paper comes from a large online personal finance website. The site provides a service that connects users' financial accounts so that user can see all of their accounts in a single location. The site allows for users to easily see summaries of their income, spending, debt, and investments across all of their accounts and has other features such as budgeting or financial goal-setting. The site has grown rapidly, from under 300,000 users in 2007 to more than 3 million active users by 2013. This large userbase has yielded a database of more than 5 billion transactions across over 10 million individual

\footnotetext{
${ }^{5}$ See Berga, Nelsonb, and Rietzc (2008) and Justin Wolfers, Eric Zitzewitz (2006) for discussions of prediction market accuracy and interpretations.
} 
accounts. These accounts span all manner of household financial products including checking accounts, savings accounts, credit cards, loans, property and mortgage accounts, equity portfolios, and retirement accounts.

The data are automatically linked from financial accounts to the website, allowing for less measurement error and potential recollection biases relative to other survey-based household financial data. In this paper, we focus primarily on two aspects of the data. The first is on paycheck income derived from government employers. To identify users with relevant employers, we take a similar approach as in Baker (2014), but focusing on state and federal government agencies rather than publicly-traded companies. We match users to their employers using textual descriptions from users' direct deposit transactions. Direct deposit transfers into checking accounts are generally observed with little error, allowing us to focus on these paycheck deposits and exclude other sources of income. Direct deposit transaction descriptions are generally characterized by indicators that the transaction is a direct deposit, a string representing an employer or agency, and anonymized identifiers. ${ }^{6}$ Our strategy for matching allows us to ignore punctuation and limited misspellings and is mainly drawn from the inspection and testing of set of several million paycheck transaction descriptions.

Our paycheck matching strategy yields a set of 148,311 users. 91,158 of these are employed by 42 state governments to be used as the control group during and surrounding the shutdown period. 57,153 users are able to be matched to 19 different federal agencies including NASA, the Securities and Exchange Commission, the Senate and the House of Representatives, the military, and a range of federal departments such as Labor, the Interior, Transportation, and State. We restrict to a balanced panel of users present in the data from January 2013 to December 2013. Given the strategy we employ, there is unlikely to be measurement error in agency-employee matching at the individual user level. This is due to the fact that a given government agency or department has a near uniform description attached to its direct deposit transactions. Thus, an error in matching would likely miss an entire class of employees or be unable to match any employee from a given agency rather than having only some employees matched while others are unmatched. One important caveat is that the paycheck transactions that we observe are net of any taxes or benefits withheld from employee paychecks. Thus, we cannot directly observe 401k contributions, federal and state taxes, or healthcare premiums paid out of gross pay.

In addition, Using data from the OMB's list of federal agency contingency plans, we note the fraction

\footnotetext{
${ }^{6}$ Some examples of such descriptions are: "DEPT JUSTICE DIRECT DEP XLWK", "PAYROLL DEPOSIT HHS”, and "TRANSIDRRRR81 STATE TENNESSDIR"
} 
of the employees at each agency or department that were affected by the government shutdown. ${ }^{7}$ The fractions of employees affected ranged from $26 \%$ or less at the Department of Veterans Affairs, Customs and Border Patrol, the Department of Justice, and Department of Transportation to more than $85 \%$ at the IRS, NASA, EPA, Department of Education, and Department of Commerce. In addition, a number of agencies, including the federal court system and Supreme Court, active duty military members, the US Post Office, and the FDA were unaffected by the shutdown due to exemption or other sources of funding.

Our second focus is on transactional spending data derived from bank, debit, and credit card transactions. These data offer a rich view of spending by users and comprise the vast majority of total household spending among users. Each transaction is time-stamped, has a full description and is generally also matched to information about the merchant. From this merchant and descriptive data, the site automatically categorizes each transaction into one of over 100 categories (such as 'Groceries', 'Gasoline', 'Student Loans', 'Fast Food', or 'Mortgage Payment') in order to provide easily readable spending and income breakdowns to the user. From these data, we can derive measures of total household spending across all categories as well as subsets of spending based on the categorization of the transactions. One potential omission is that of cash transactions. Cash transactions can only be fully observed when a user manually enters them, though strong assumptions about cash spending can also be made by observing ATM and bank withdrawals. An estimated 6-8\% of total spending is done with cash in the United States, compared to approximately $3-4 \%$ of spending done with cash in the sample data.

These data are described in more detail in Baker (2014), along with a number of ancillary tests and descriptive statistics. Steps are taken to test whether the finances userbase of the website can yield relevant insights into the financial behavior and characteristics of a nation as a whole. Baker (2014) lays of a number of tests and re-weighting procedures, comparing data from the website to other measures of household financial behavior such as Census Retail Sales, the Survey of Consumer Finance, Zillow house price data, and the CPS, finding very strong relationships after conditioning on differences in demographics between website users and the nation as a whole.

In conjunction with the financial data, users provide demographic information such as age, sex, marital status, and the size of the household. Users also list whether they are a homeowner, their profession, their level of education, their income level, and their location. Due to the nature of the website, usage patterns suggest that it covers the entirety of financial transactions for groups who make joint financial

\footnotetext{
${ }^{7}$ Found at the Office of Management and Budget Agency Contingency Plans.
} 
decisions. Thus, we equate a user of this financial website with a head-of-household in the Current Population Survey (CPS) or a 'consumption unit' in the Consumer Expenditure Survey (CES). For example, a 'user' represents the entirety of household spending for married couples but only represents an individual's spending for an unmarried individual living with roommates.

It is important to note that our identification strategy is local to government employees. It is possible that consumption patterns differ for government employees and other groups. Our sample is arguably representative of of both state and federal government employees in 2010. Being a software start-up, in early years the demographics of the website were very different than those of the national as a whole. Key user characteristics like gender and age were starkly different than the national distribution in 2007 (being younger and more male). While the demographics of the user-base were initially very different, they have become much closer to a representative national distribution by 2013 as the user-base grew dramatically. Moreover, conditional on observable household demographic and locational characteristics, financial behavior among the users seems to track closely to national averages. Moreover, the existing userbase differs from the population of federal and state employees by less than it does from the total US population (eg. both have fewer unbanked households or extremely high-income households). Summary statistics of the sample population can be found in Table 3. Baker (2014) discusses using household weights derived from CPS weightings and self-reported demographic and locational information in order to obtain more externally valid estimates. Our results are robust to using equivalent household weights.

\section{Results}

\subsection{Income and Spending}

Figure 1 displays variants of equations 1 and 2. The top row shows the coefficients for fixed effects for each month for federal and state government workers, which are respectively the blue squares and red triangles. Dashed lines show 95\% confidence intervals for each point estimate. In the left panel the dependent variable is income, while in the right hand panel the dependent variable is spending during the final six months of 2013. The first three weeks of October, during which the Shutdown affected incomes, is shaded. The left hand panel shows that the shutdown did affect incomes. In October 2013 there was an approximate 20-25\% drop in incomes for federal government workers. This is drop is followed by a rebound in the weeks following the shutdown. There is a large spike in incomes in the final week 
of October, but we see smaller increases in November and December which is consistent with some workers not being paid until later in the year. There is no noticeable change in income for the control group, state government workers, which is expected as this group was not affected by the shutdown.

The right panel shows that the shutdown impacted spending. For federal government workers, there is a small drop in the second period week of the shutdown, and a larger drop in the third week of the shutdown. This pattern is consistent with credit constraints and federal government workers exhausting their savings. The largest drop is seen in the third week of the shutdown, after the end of the shutdown was announced. This pattern is not consistent with alternative explanations such as the drop in spending being driven by revised beliefs about permanent income. Following the shutdown, there is a rebound in spending. This rebound is driven primarily by durable purchases and will be discussed further in section 3.2. Again we see no noticeable change in spending for the control group, state government workers, which provides supporting evidence that the observed patterns are not driven by seasonality

The second row of Figure 1 shows the difference in difference specification in equations 1 and 2 . Each point estimate shows the difference in the outcome for federal and state government workers in the last six months of 2013. Dashed lines show 95\% confidence intervals for each point estimate. Both the income and spending differences for federal and state government workers are statistically significant at the 0.05 level. The final row of Figure 1 repeats the analysis in the first row for 2012, where the federal government did not shut down. In this placebo specification, there is not a significant difference between federal and state government workers, providing supporting evidence for our identifying assumptions and that the observed patterns are driven by the shutdown.

Table 4 makes the graphical evidence presented in Figure 1 explicit. The first row shows an interaction between the shutdown being in effect and an individual working for the federal government. Column (1) indicates that the shutdown was associated with a 23.4 percent drop in income for federal government workers relative to state government workers. The drop is significant at the 0.01 level. Column (2) shows the partial rebound in the week immediately following the shutdown. The rebound is not full, since some federal government workers did not receive backpay until November or December. Column (3) indicates that during the shutdown there was an approximate 10.7 percent decrease in spending for federal government workers relative to state government workers. The effect is significant at the 0.01 level. Column (5) shows that there is a rebound in spending following the shutdown, however the rebound in spending is not as large as the prior drop. 
Column (4) adds a a triple interaction between the shutdown being in effect, an individual working for the federal government and the probability that the individual was furloughed, $\mathbb{1}[t=$ Shutdown $] *$ $\mathbb{1}[\text { FedGov }]_{i t} * \mathbb{1}[\text { Furloughed }]_{i t}$ where the subscript $i$ denotes the individual and the subscript $i$ denotes the time period. The results indicate that the drop for furloughed workers is roughly twice as large as that for workers who were not furloughed. This could be consistent with either time allocation or home production affecting consumption, and this will be discussed further in section 3.2.4. The results indicate a spending elasticity to income of 0.302 and a marginal propensity to consume of approximate 0.31. Column (1) shows that there is no significant difference in the income decline for furloughed workers, suggesting that the results are indeed driven by workers being sent home without pay during the shutdown.

Columns (6)-(8) collapse the results to the daily level by agency, providing an additional specification and robustness check. The results are quite similar to the main results and significant at conventional significance levels. The results confirm at there is a large drop in spending for federal government workers during the shutdown, relative to state government workers. Moreover this drop in spending is much greater for workers who were furloughed during the shutdown, and sent home without pay rather than made to work without pay. The results also confirm the rebound in spending following the shutdown.

\subsection{Drivers of Spending Response}

\subsubsection{Differential Categorical Spending Declines}

Table 5 breaks down the spending decline between various categories during the shutdown, along with the differential decline for furloughed workers. The category is written above each column and panel. The first row shows food related expenditures. For all government employees, there a significant decline in restaurant spending and no decline in fast food and grocery spending. There is a larger decline in fast food and grocery related spending for furloughed workers. This could be due to home production, furloughed workers could cook at home rather than eating fast food and spend more time preparing less costly meals.

Categorical discussion here.

Changes in time allocation can impact consumption through two non-mutually exclusive channels. 
First, if consumption and leisure are substitutes and non-separable, an increase in time available for leisure will reduce consumption. Second, individuals may engage in home production, for example cleaning themselves rather than hiring outside help. Section 3.2.4 discusses the implications of consumption responded due to home production or increased leisure. The categorical spending declines provide evidence of both channels, however our design does not allow us to quantify the impact of each channel on the time-allocation related decline in consumption.

\subsubsection{Permanent Income}

One important driver of household consumption decision is the arrival of new information about the future path of household income. Theory, and the well-established standard Euler equation for consumption, tell us that households will react to unanticipated news about changes in their permanent income path with a swift revision to their consumption with an elasticity nearing one. Moreover, empirical work has consistently found strong impacts of unexpected permanent income shifts. ${ }^{8}$

The government shutdown in 2013 may have changed households beliefs about the likelihood that they would maintain steady increases in pay and about the security of their positions in both the shortand long-run. The political crisis the precipitated the shutdown could have driven federal employees to believe they may be more likely to be subject to furloughs, pay freezes, or more intense political debates about public-sector compensation.

The standard Euler equation, along with the bulk of empirical research, would predict that a downward shift in beliefs about permanent income would be accompanied by an immediate and permanent decline in consumption equal to the size of the permanent income shock. That is, affected households would decrease spending when the shutdown occurred and their beliefs shifted and would not increase spending to previous levels even after their temporary income disruption was relieved.

We test this hypothesis by looking at income 3 months prior to the shutdown and 3 months afterward, when all foregone pay had been repaid to the households, and comparing federal to state employees who were unaffected by the shutdown. ${ }^{9}$ We find no significant difference in spending, at a very high precision,

\footnotetext{
${ }^{8}$ Theory dating back to Friedman (1957) has posited diverging responses to transitory and permanent income shocks. Flavin (1981), Campbell (1987), Carroll (2009) and Kaplan and Violante (2010) have provided further theoretical justification for strong consumption responses to permanent income shocks in a wide range of settings. Work including Gruber (1997), Wolpin (1982), Pistaferri (2001) and Jappelli and Pistaferri (2007) has demonstrated these strong responses empirically. This work, alongside many other papers, they have provided much evidence for large household consumption responses to permanent income shocks, although sometimes finding responsiveness somewhat less than one, as theory would predict.

${ }^{9}$ One concern is that we find no significant differences here when looking at differential spending patterns between affected
} 
allowing us to reject a permanent decline in household spending. Moreover, we find significant declines in spending during the shutdown, followed by a rapid recovery in spending upon the ending of the shutdown, suggesting that the decline in household spending was not permanent and likely not caused by shifts in permanent income expectations.

\subsubsection{Credit Constraints}

The role of credit constraints in impacting household consumption behavior is often highlighted when examining unexpected declines in income. In the classic permanent income hypothesis framework, unexpected temporary declines in income only manifest themselves as declines in consumption if households are credit or liquidity constrained..$^{10}$

Given most affected federal employees knew that they would be repaid all foregone income following the conclusion of the government shutdown, they would experience no expected change in lifetime income. Because they would only be subject to a temporary decline in income, this framework would predict a decline in consumption only among those households who were unable to borrow or draw on liquid savings to smooth their consumption during the shutdown until their regular income resumed. Unable to borrow or draw on savings to finance current consumption, constrained households would be predicted to cut and defer spending during the government shutdown. Thus, any decline in spending would be only seen among households without sufficient savings or borrowing capability.

We test this theory using savings, and test whether liquid assets (and/or total assets) and credit availability seemed to ameliorate declines in spending here. We aggregate household savings in the nine months preceding the shutdown, and interact savings with he federal government by shutdown down indicators $\mathbb{1}\{i=t\}_{t} \times \mathbb{1}\{\text { Gov }\}_{i} \times$ Savings. If liquidity constraints played a large role in the consumption drop during the shutdown, we would expect the coefficient on this interaction to be large and significant

federal workers and state government employees because of a strong correlation in the changes in income expectations among these two groups. We also construct a control group composed of a random sample of private sector workers at publicly traded firms. Using this as an alternate control, we also find no evidence supporting a persistent decline in income among the affected federal government employees.

${ }^{10}$ See, for instance, Bishop and Park (2011) which demonstrates that marginal propensities to consume drop steeply following a relaxation in binding borrowing constraints. Kaplan and Violante (2014) and Eggertsson and Krugman (2012) both spell out mechanisms by which credit or liquidity constrained households become more responsive to income changes with potential macroeconomic consequences. Zeldes (1989), Johnson, Parker, and Souleles (2006), and Blundell, Pistaferri, and Preston (2006) also estimate a higher level of consumption elasticity among households with less credit and net worth. In addition, recent work has suggested a potentially large role of credit constraints in the consumption decline seen during the Great Recession (eg. Baker (2014), Mian, Sufi, and Rao (2013) and Dynan (2012). 
as households with higher savings would not face liquidity constraints.

Table A3 presents a specification in which the federal government by shutdown down indicators $\mathbb{1}\{i=t\}_{t} \times \mathbb{1}\{\text { Gov }\}_{i}$ are interacted with savings before the shutdown. Savings are defined as the sum of all income minus transactions in the nine months prior to the shutdown, in thousands of dollars. The results indicate that for every one thousand dollars saved before the shutdown, consumption during the shutdown increased by about 0.1 percent or 3 dollars. This is evidence that credit constraints may have played a role in the consumption drop seen following the shutdown, however given the small magnitudes it is unlikely that credit constraints can explain the entirety of the drop.

More directly, we investigate whether household credit and liquidity constraints drove the observed declines in consumption by turning to another aspect of the website's financial data. In addition to transactional data, the site archives daily balance data for equity, retirement, property, real estate, and loan accounts. We also observe both credit card balances as well as credit limits, allowing us to see how much room to borrow on credit cards consumers have. Lines of credit, such as HELOCs, are observed in a similar manner as credit cards, with data on the amount used and the amount of credit still available.

From these data, we can define three measures of credit and savings. Firstly, we define 'available credit' as the remaining room to borrow on existing credit cards in addition to open lines of credit that the households have access to. Credit cards with no pre-set borrowing limit are measured as having a $\$ 200,000$ credit limit, equal to the 99.9 th percentile of credit cards. We define 'liquid savings' as the combined balance of all checking accounts, savings accounts, reported cash holdings, and non-retirement equity accounts. Finally, 'illiquid savings' are defined as all other net assets such as real estate, vehicles, and retirement accounts.

\subsubsection{Consumption Types and Home Production}

Changes in time allocation due to the shutdown could also affect consumption though multiple channels. Theory predicts that if utility is non-separable in consumption and leisure, individuals smooth the marginal utility of consumption, $\mathbb{E}_{t-1}\left[u\left(c_{i, t-1}, l_{i, t-1}\right)\right]=u\left(c_{i, t}, l_{i, t}\right)$, and an adjustment in leisure can lead to a consumption change. Home production can also cause a decline in consumption if more time is available. Both of these explanations have been noted, respectively by Haider and Stephens (2007) and Aguiar and Hurst (2007) and Aguiar, Hurst, and Karabarbounis (2013), as potential explanations for the sharp drop in consumption seen at retirement, counter to the consumption smoothing predicted by the 
permanent income hypothesis. As well as being of theoretical interest, the underlying reasons behind a time allocation have important welfare consequences in terms of designing social insurance programs. If the consumption drop following unemployment is due to increased leisure rather than liquidity constraints, this has implications in the design of optimal unemployment programs in the tradition of Baily (1978) and Chetty (2006).

Other work by Arslan, Guler, and Taskin (2014) suggests similar effects hold for unemployment spells. Burda and Hamermesh (2010), demonstrate cyclical variation in unemployment leads to variation in home production but little impact of long-term unemployment. The framework of the 2013 government shutdown allows us to separate the effects of leisure and home production from other channels, since some workers were sent home while others were required to work without pay.

During the 2013 US government shutdown, some agencies furloughed nearly all of their workers. Other agencies deemed services essential, and required the majority of employees to continue working without pay. This latter group would have been unaffected by increased home production or leisure, and hence any decline in consumption is due to a credit constraint effect. To identify the effects of credit constraints and home production or leisure, we estimate equations 1 and 2, adding an an interaction term for workers that were in an agency where more than two thirds of workers were furloughed, $\mathbb{1}\{i=$ $t\}_{t} \times \mathbb{1}\{\text { Gov }\}_{i} \times \mathbb{1}\left\{\right.$ Furlough $_{i}$. The coefficient on the interaction term provides an estimate of the difference in consumption that is driven from home production or leisure rather than a temporary drop in income and credit constraints. A large negative coefficient is consistent with changes in time allocation leading to a drop in consumption, which could be due either to leisure or increased home production.

One primary benefit of our data and identification strategy is that it is possible to separately examine various types of household spending rather than only considering spending as a whole. This allows for a greater understanding of household smoothing behavior and also lets us highlight differences between households that were affected by the federal furloughs and loss of pay from those solely affected by the loss of pay. We can also use the richness of the data and fine categorical data to look for direct evidence of home production or leisure spending. We can re-estimate our main specification separately for each category, including the triple difference furlough interaction. If furloughed workers are engaging in home production, this would be evident through decreased spending on items such as restaurants, child-related expenses or home and garden related expenses. Evidence of increased leisure time could be present in categories such as entertainment, office supplies and spending in venues related to leisure activities such 
as coffee shops or bars.

To further examine whether the observed drop is due to home production or increase leisure time, we can examine categorized transaction data. Tables A2 and 5 show equation 2 broken down by individual categories. There are large drops in categories such as eating out, shopping and office supplies which are consistent with a number of interpretations. However, we see larger drops for furloughed workers relative to excepted workers in categories such as dining out, groceries, baby supplies, office supplies, entertainment and kid's activities, which is consistent both with increased leisure activity and home production in areas such as food preparation and child services.

Tables A2 and 5 also provide valuable placebo tests, which serve as a check regarding both our empirical strategy and the validity of our category data. We do not see drops in consumption in categories that are unlikely to be cut due to a transitory income shock. We see no differential change in health spending, which is likely to be inelastic and driven by adverse health shocks. We also see no effect on mortgage and auto payments, which could adversely affect credit scores and have large implications if missed.

For instance, column 4 of Table 4 shows that while non-furloughed federal workers saw a $7 \%$ decline in spending during the shutdown, those households that had a furloughed worker saw spending decline about twice as much. Column (2) of Table 4 demonstrates that this larger decline in spending was in spite of any difference in how household income were affected between these two groups. Observing particular types of spending allows us to pin down the types of spending that led to this divergence.

Table 5 displays results showing impacts on federal employees affected by the disruption in pay during the shutdown as well as those affected by both the disruption in pay and the furlough. At the top of column (1), for example, we see a decline in spending at restaurants across all affected employees of approximately $8 \%$ as well as an additional negative and insignificant decline in restaurant spending among furloughed employees of approximately $4 \%$. In a number of the categories in Table 5, we see differential household spending responses across affected employees in general and furloughed employees in particular.

Consistent with an expected decline in commuting among the furloughed workers, we see significantly less spending on automobiles, public transport, and gasoline compared to other affected federal employees. We also see a larger decline in fast food and groceries expenditures. This may be consistent with previous work suggesting that out-of-work individuals generally cut back on consumption of food 
outside the home and also are able to shop for groceries more judiciously, thus cutting expenditures while maintaining similar 'consumption'. Spending on home services is likewise disproportionately cut by furloughed households, as staying home from work enables households to limit spending on things like maid services and child care. One category that sees a disproportionate increase among the furloughed employees is 'entertainment' spending such as going to movies or other outside-the-home events. This suggests some substitution into paid leisure activities given additional non-work hours. There is little differential affects on spending on more constrained categories like insurance, medical care, and education.

\section{Robustness}

Still to come.

\subsection{Placebo Results in 2012}

Still to come.

\section{References}

Aguiar, M., And E. Hurst (2007): "Lifecycle Prices and Production," American Economic Review, 97(5), 1533-59.

Aguiar, M., E. Hurst, and L. Karabarbounis (2013): “Time Use During the Great Recession,” American Economic Review, 103(5), 1664-1696.

Arslan, Y., B. Guler, And T. TASKin (2014): "Home Production and the Optimal Rate of Unemployment Insurance," Unpublished Mimeo.

B AILY, M. (1978): “Some Aspects of Optimal Unemployment Insurance,” Journal of Public Economics, (10), 379-402.

BAKER, S. R. (2014): “Debt and the Consumption Response to Household Income Shocks," Stanford University Working Paper.

BISHOP, T., AND C. PARK (2011): "Borrowing constraints and the marginal propensity to consume," Journal of Economic Policy, 33(4), 1-25. 
Blundell, R., L. Pistaferri, And I. Preston (2006): “Consumption Inequality and Partial Insurance," American Economic Review, 98(5), 1887-1921.

Burda, M., AND D. S. HAMERMESH (2010): “Unemployment, market work and household production," Economics Letters, 107(2), 131-133.

Burwell, S. (2013): "Impacts and Costs of the October 2013 Federal Government Shutdown," Executive Office of the President of the United States.

Campbell, J. (1987): "Does Saving Anticipate Declining Labor Income? An Alternative Test of the Permanent Income Hypothesis," Econometrica, 55, 1249-73.

Carroll, C. D. (2009): "Precautionary Saving and the Marginal Propensity to Consume Out of Permanent Income," Journal of Monetary Economics, 56(6), 1249-73.

Chetty, R. (2006): “A General Formula for the Optimal Level of Social Insurance,” Journal of Public Economics, 90(10), 2351-2356.

DynAN, K. (2012): “Is a Household Debt Overhang Holding Back Consumption?," Brookings Papers on Economic Activity.

EgGers, A., And A. Fouirnaies (2014): “The Economic Impact of Economic News,” Unpublished Mimeo.

Eggertsson, G., And P. KRugman (2012): "Debt, Deleveraging, and the Liquidity Trap: A FisherMinsky-Koo Approach,” The Quarterly Journal of Economics, 127(3), 1469-1513.

FlaVin, M. (1981): “The Adjustment of Consumption to Changing Expectations about Future Income," Journal of Political Economy, 89, 974-1009.

Friedman, M. (1957): "A Theory of the Consumption Function,” Princeton: Princeton University Press.

Gruber, J. (1997): “The Consumption Smoothing Benefits of Unemployment Insurance,” American Economic Review, 87(1), 192-205.

HAIDER, S., And M. StePhens (2007): "Is There a Retirement-Consumption Puzzle? Evidence Using Subjective Retirement Expectations," Review of Economics and Statistics, 89, 246-64.

Jappelli, T., And L. PistaferRi (2007): "Do People Respond to Tax Incentives? An Analysis of the Italian Reform of the Deductibility of Home Mortgage Interests," European Economic Review, 51, $247-271$. 
(2010): “The Consumption Response to Income Changes," Annual Review of Economics, 2, 479-506.

Johnson, D., J. PARKer, And N. Souleles (2006): "Household Expenditure and the Income Tax Rebates of 2001," American Economic Review, 96(5), 1589-1610.

Kaplan, G., And G. Violante (2010): "How Much Consumption Insurance beyond SelfInsurance?," American Economic Journal: Macroeconomics, 2(4). (2014): “A Model of the Consumption Response to Fiscal Stimulus Payments," Econometrica.

Mian, A., A. Sufi, And K. RaO (2013): "Household Balance Sheets, Consumption, and the Economic Slump," The Quarterly Journal of Economics, 128(4), 1687-1726.

PISTAFERRI, L. (2001): "Superior Information, Income Shocks and the Permanent Income Hypothesis," Review of Economics and Statistics, 83(3), 465-476.

Wolpin, K. (1982): “A New Test of the Permanent Income Hypothesis: The Impact of Weather on the Income and Consumption of Farm Households in India," International Economic Review, 23(3), $583-594$

ZELDES, S. (1989): “Consumption and Liquidity Constraints: An Empirical Investigation,” Journal of Political Economy, 97(2), 1469-1513. 
Figure 1: Overlay of Results for Federal and State Government Workers

Income - 2013

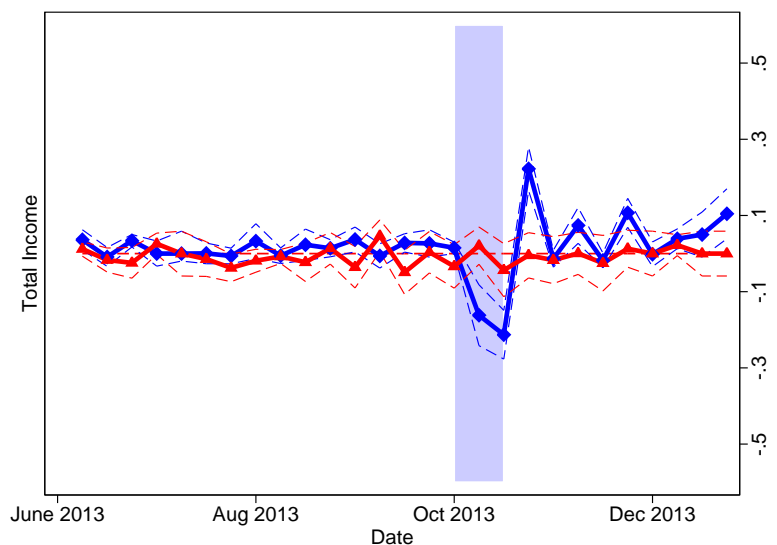

Income Diff. - 2013

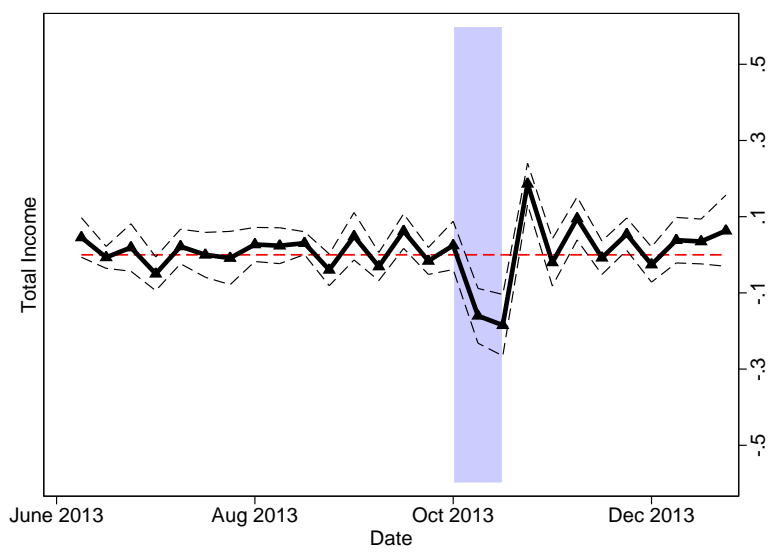

Income Placebo - 2012

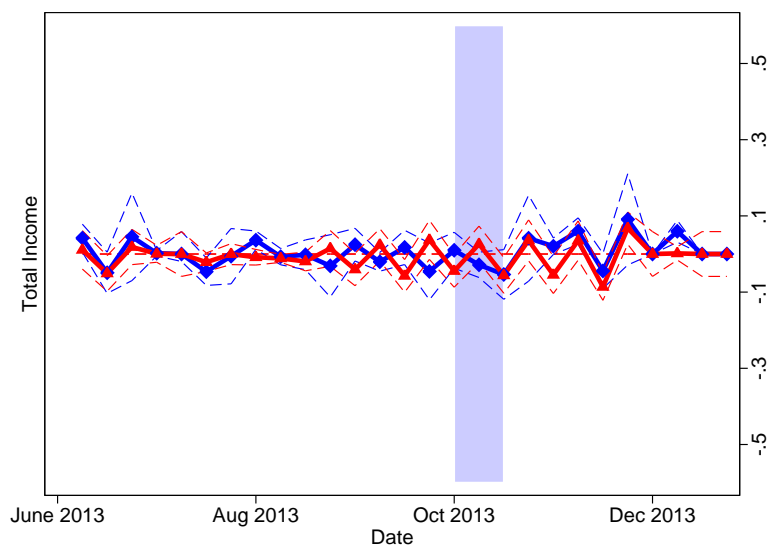

Spending - 2013

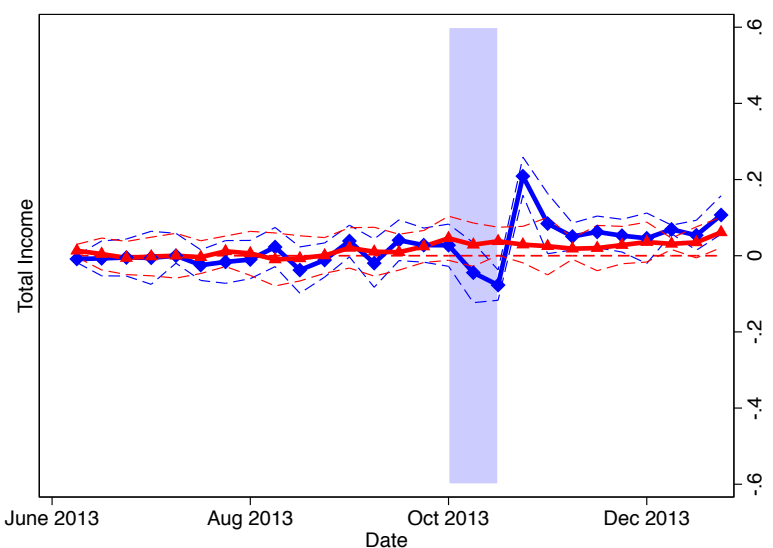

Spending Diff. - 2013

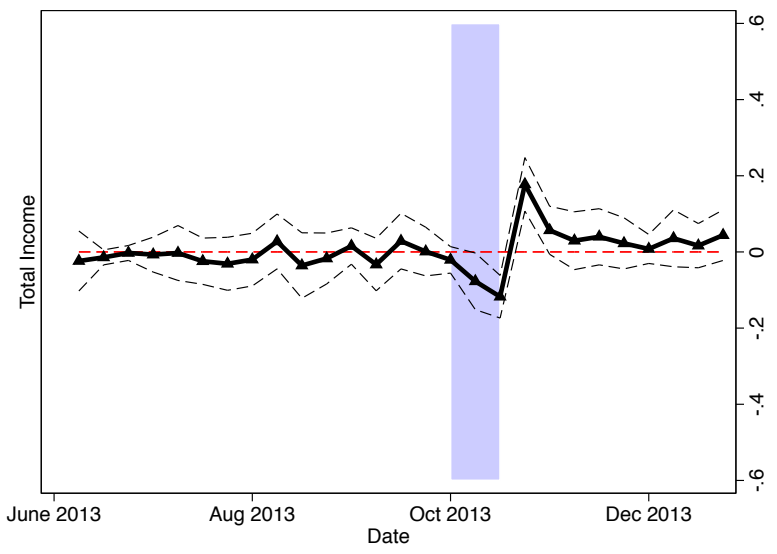

Spending Placebo - 2012

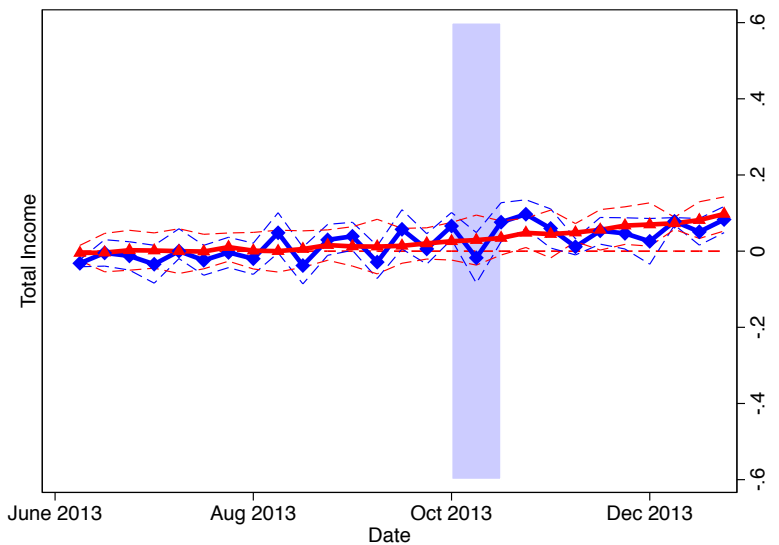

Notes: The dependent variable in each specification is log income or the log total amount spent in one week periods during 2012. Each figure figure plots the coefficients on the fixed effects from regressions of income on time period dummies. The month of October is shaded, during which the federal government shutdown took place in 2013. The figure on the left restricts federal government workers to those who were excepted during the shutdown, and made to work without pay during the shutdown. The figure on the left restricts federal government workers to those who were furloughed during the shutdown, and sent home without pay. The third figure plots the coefficients $\beta_{y}$ of interactions between indicators of whether or not an individual belongs to the treatment group of federal government areas and time period dummies, $y_{i t}=\alpha_{t}+\alpha_{i}+\sum_{y=0}^{T} \beta_{y} \mathbb{1}[y=t] * \mathbb{1}\left[F e\left\{\begin{array}{l}2 \\ G o v\end{array}\right]_{i t}+\gamma X_{i t}^{\prime}+\epsilon_{i t}\right.$. The dashed lines show a 95\% confidence interval. Income specifications include individual fixed effects. Standard errors are clustered at the agency level. 
Figure 2: Transactions During the Shutdown for Furloughed and Excepted Workers

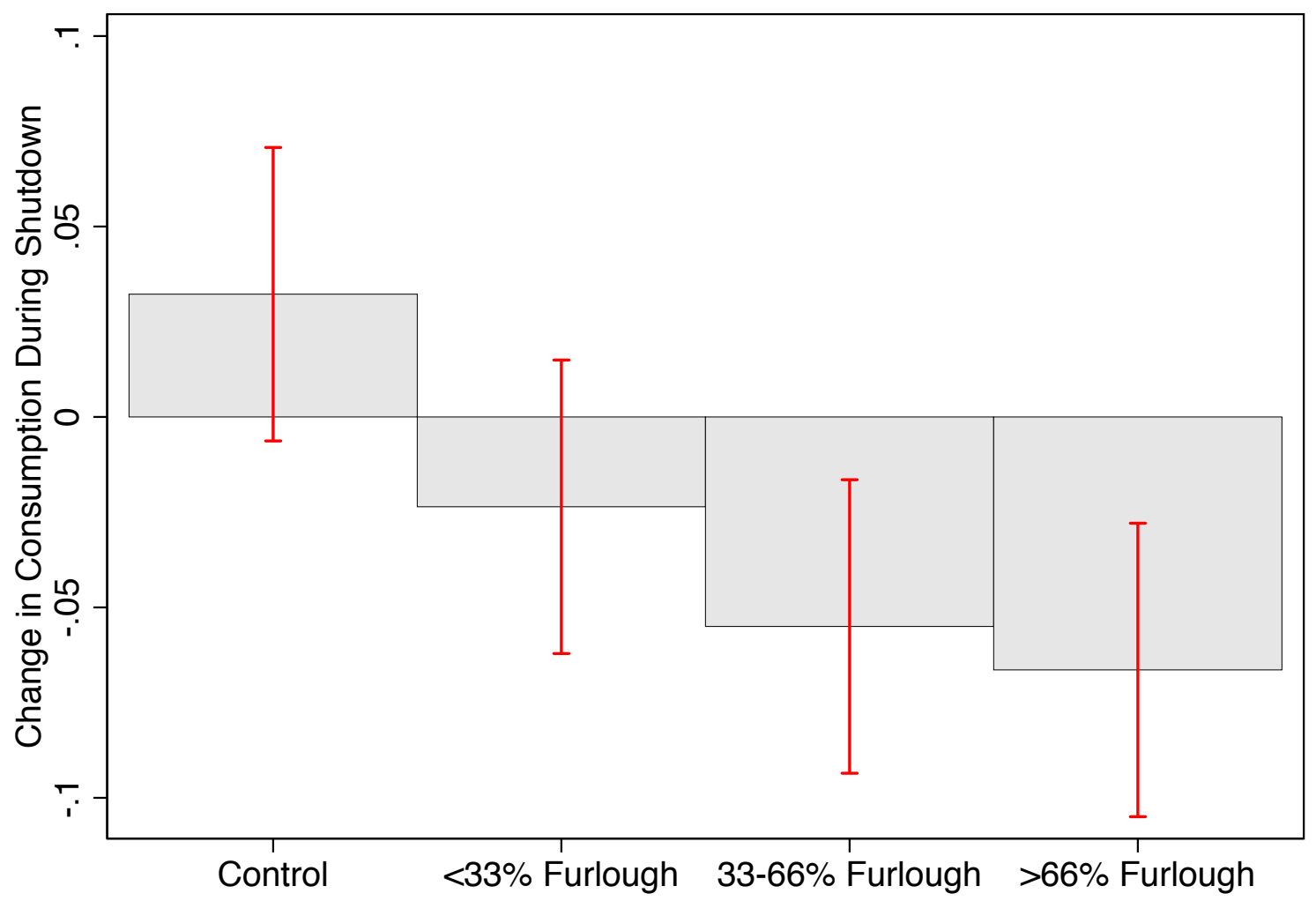

Notes: The dependent variable in each specification is the log total amount spent in two week periods during 2013. Each gray bar shows the coefficients $\beta_{y}$ of an indicator of whether or not the government shutdown is in effect, $y_{i t}=$ $\alpha_{t}+\alpha_{i}+\sum_{y \in S} \beta_{y} \mathbb{1}[y=t]+\gamma X_{i t}^{\prime}+\epsilon_{i t}$. The red bars show a 95\% confidence interval. All specifications include agency, date-group and federal government by week fixed effects. Standard errors are clustered at the agency week level. 
Figure 3: Anticipation of the Shutdown was Minimal Until One Week Before the Shutdown Occurred Number of News Stories Mentioning "Government Shutdown"

Probability of Shutdown

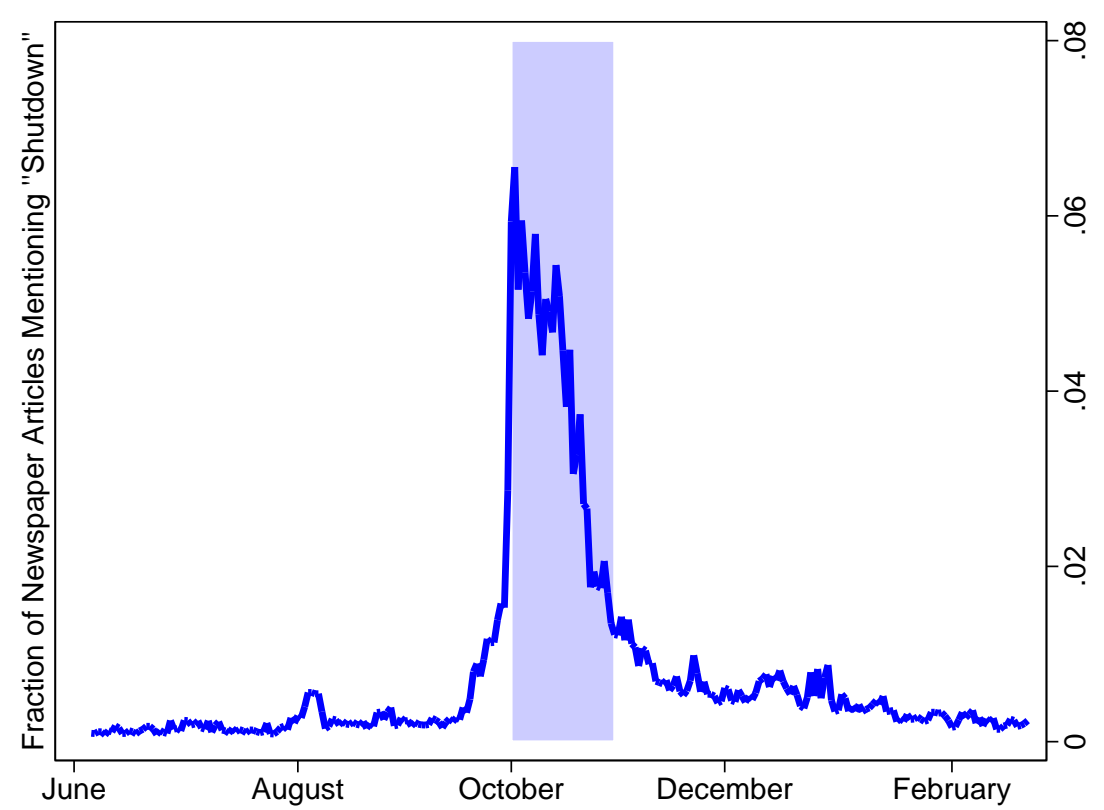

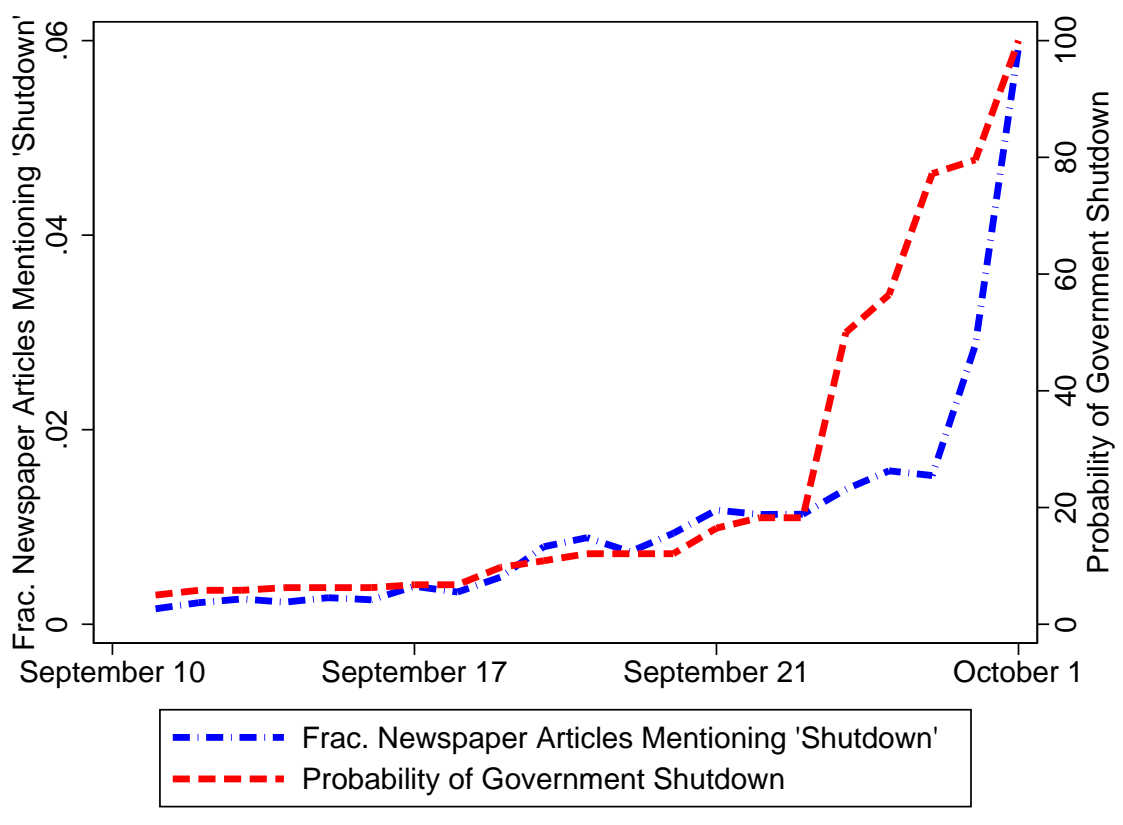

Notes: The panel on the left shows the fraction fraction of newspaper articles mentioning the phrase "government shutdown". Both of these ratios are calculated using data from all US newspapers in the Access World News NewsBank database, comprised of nearly 2000 newspapers in 2014, taking the total number of newspaper articles mentioning "government shutdown" as a fraction of the total number of newspaper articles each day. Query was run on June 15th. The panel on the right shows two series. In red is the probability of the federal government shutting down before October 1 from the online prediction market Inkling Markets, which featured the question "Will the U.S. government shut down due to lack of funding before 1/1/14?". In blue is the fraction of newspaper articles mentioning the phrase "government shutdown". 
Figure 4: Spending Difference by Category I

Dining

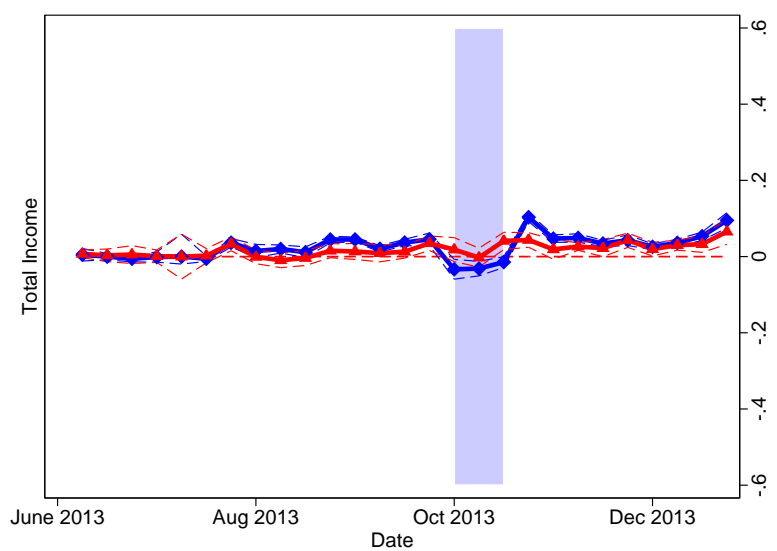

Durables

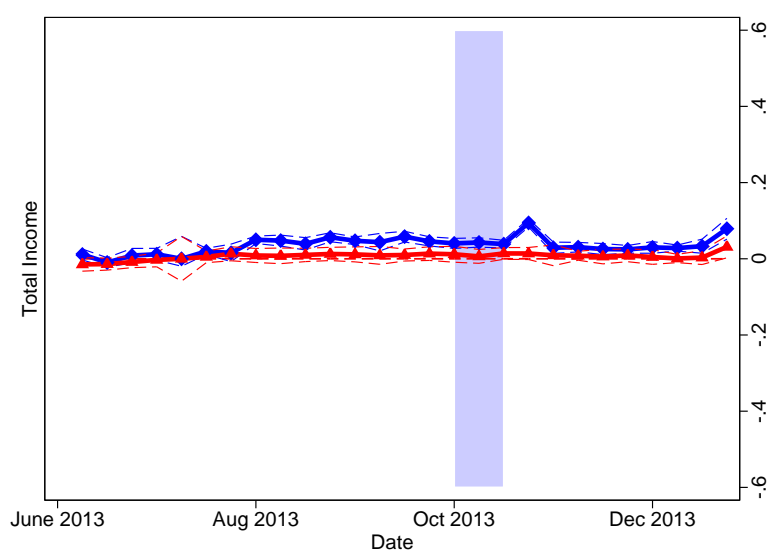

Groceries

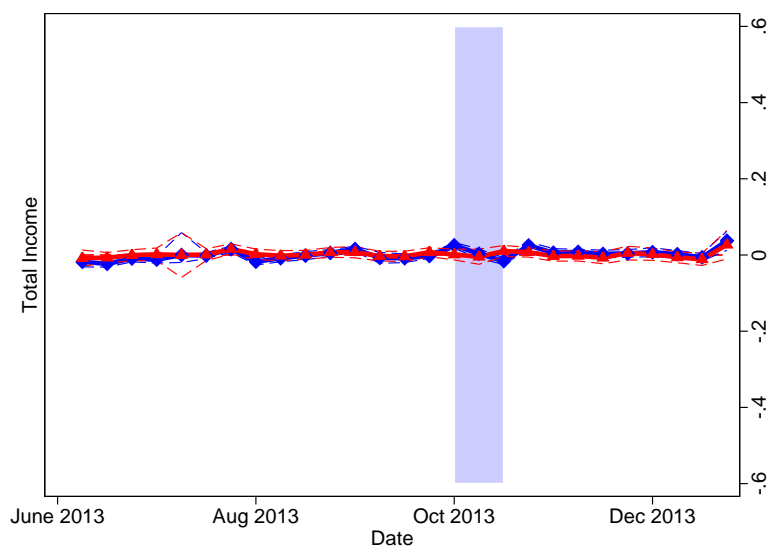

Cash \& Check

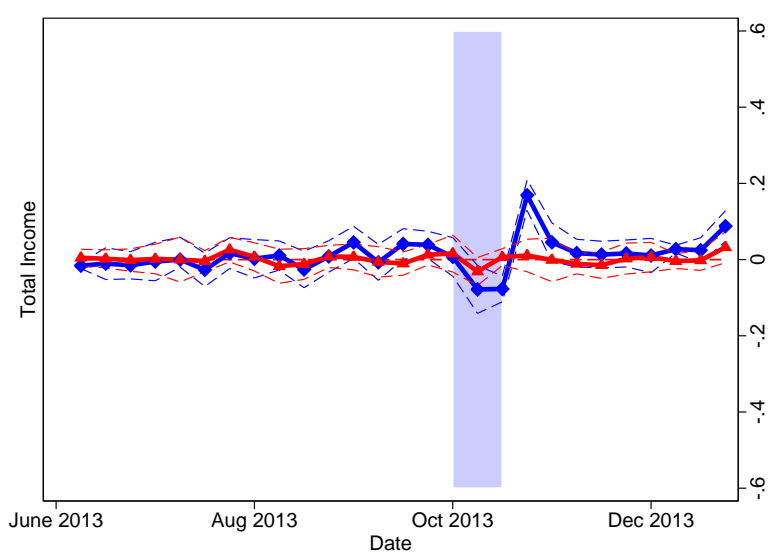

Home

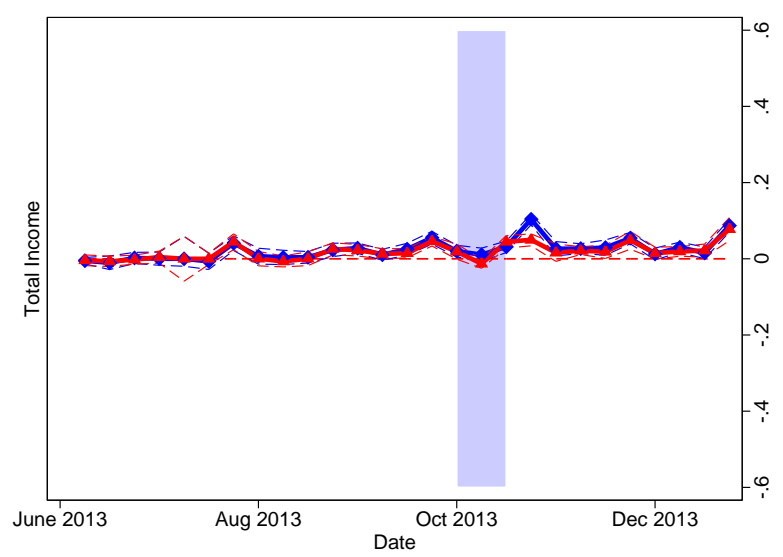

Health

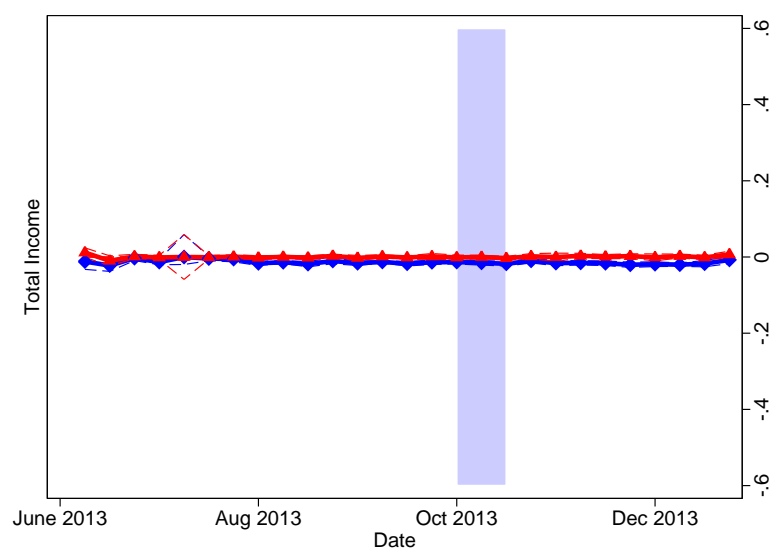

Notes: The dependent variable in each specification is the log total amount spent in a specific category during one week periods during the second six months of 2013. Each category is listed above the panel. The figures plot the coefficients $\beta_{y}$ of interactions between indicators of whether or not an individual belongs to the treatment group of federal government areas and time period dummies, $y_{i t}=\alpha_{t}+\alpha_{i}+\sum_{y=0}^{T} \beta_{y} \mathbb{1}[y=t] * \mathbb{1}[\text { FedGov }]_{i t}+\gamma X_{i t}^{\prime}+\epsilon_{i t}$. The month of October is shaded, during which the federal government shutdown occurred. The dashed lines show a $95 \%$ confidence interval. Standard errors are clustered at the agency level. 
Figure 5: Spending Difference by Category - cont.

\section{Effect of Shutdown}

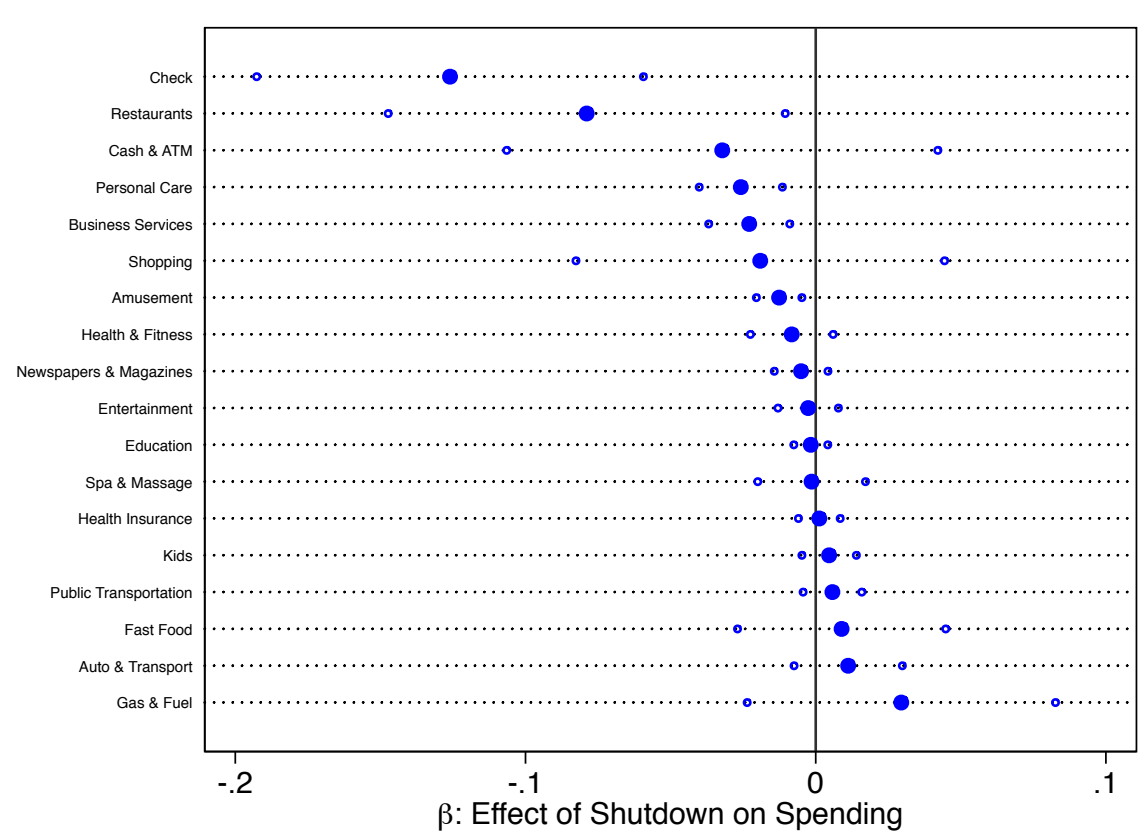

Effect of Furlough

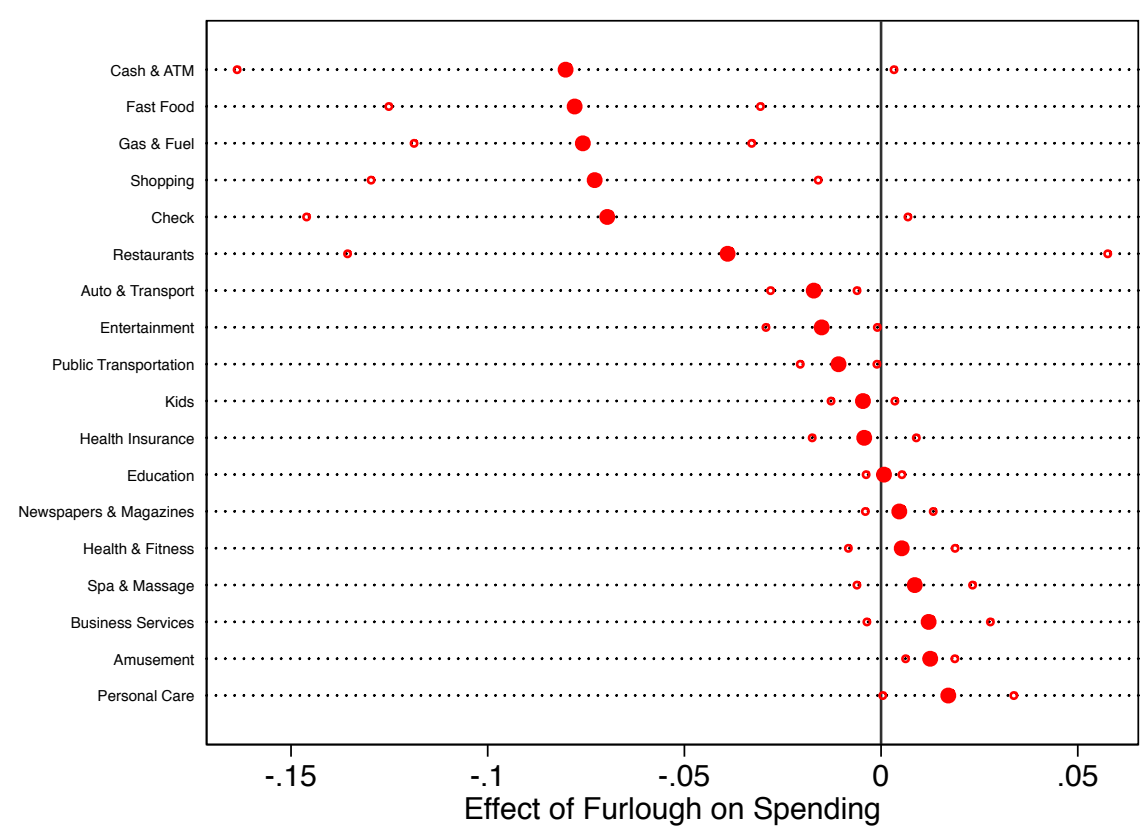

Notes: The figure on the left plots the coefficients $\beta_{1}$ of interactions between indicators of whether or not an individual belongs to the treatment group of federal government areas and time period dummies, while the figure on the left sows the coefficients $\beta_{2}$ from an additional interaction including the probability of being furloughed. The specification estimated is $y_{i t}=\alpha_{t}+\alpha_{i}+\beta_{1} \mathbb{1}[t=$ Shutdown $] * \mathbb{1}[\text { FedGov }]_{i t}+\beta_{2} \mathbb{1}[t=$ Shutdown $] * \mathbb{1}\left[\right.$ FedGov $_{i t} * \mathbb{1}\left[\right.$ Furloughed $_{i t}+\gamma X_{i t}^{\prime}+\epsilon_{i t}$. The specification include individual and time period fixed effects. The dependent variable in each specification is the log total amount spent in a specific category during one week periods during the second six months of 2013. The category is listed to the left of each coefficient. The solid circles show the relative point estimates labeled above each panel. The hollow circles show a 95\% confidence interval. Categories are sorted by magnitudes, with the largest negative effect, at the top and the largest positive effect, at the bottom. Standard errors are clustered at the agency level. 
Table 1: Timeline of the 2013 Shutdown

\begin{tabular}{|c|c|}
\hline Date & Federal Government Shutdown Event \\
\hline Sept. 10 & $\begin{array}{l}\text { House introduces H.J. Res. } 59 \text { which defunds the Patient Protection } \\
\text { and Affordable Care Act (ACA.) }\end{array}$ \\
\hline Sept. 19 & White House issues veto threat for H.J. Res. 59. \\
\hline Sept. 20 & $\begin{array}{l}\text { House votes to keep the government open only if funding is } \\
\text { halted for the ACA. }\end{array}$ \\
\hline Sept. 20 & Filibuster delivered on house floor threatening a shutdown. \\
\hline Sept. 27 & The Senate removes the provision defunding the ACA. \\
\hline Sept. 29 & $\begin{array}{l}\text { The House passes an amended version of H.J. Res. } 59 \text {, } \\
\text { which delays implementation of the ACA for one year and } \\
\text { repeals a tax on medical devices. The House also votes to } \\
\text { pay the military in the event of a shutdown. }\end{array}$ \\
\hline Sept. 30 & $\begin{array}{l}\text { The House sends another amended bill that would delay the } \\
\text { individual mandate for one year and require members of Congress } \\
\text { and staff to end employer health contributions. The Senate rejects } \\
\text { the amendments. The Senate passes the bill paying the military in } \\
\text { the event of a shutdown. The White House signs the bill into law. }\end{array}$ \\
\hline Oct. 1 & $\begin{array}{l}\text { The shutdown begins with the new fiscal year. Approximately } \\
800,000 \text { workers are furloughed. }\end{array}$ \\
\hline Oct. 5 & House votes to approve back pay to furloughed workers. \\
\hline Oct. $2-12$ & $\begin{array}{l}\text { Negotiations between congressional leaders and the White } \\
\text { House, no significant progress is made. }\end{array}$ \\
\hline Oct. $11-17$ & Federal government workers miss scheduled pay checks. \\
\hline Oct. 14 & $\begin{array}{l}\text { Senate majority and minority leaders announce a bipartisan deal } \\
\text { to end the shutdown and raise the debt ceiling. }\end{array}$ \\
\hline Oct. 16 & Senate and House pass a bill late at night ending the shutdown. \\
\hline Oct. 17 & President signs the bill into law. \\
\hline Oct. $25-28$ & $\begin{array}{l}\text { First pay days following the end of the shutdown. Federal } \\
\text { workers begin to receive back pay. }\end{array}$ \\
\hline
\end{tabular}

Notes: The events described in the table above are compiled from the authors' own tabulations, primarily from media coverage of the shutdown and government documents. The left hand column gives the date in 2013. The right hand column gives a description of an event leading up to or during the October 1-17 shutdown. 
Table 2: Federal Government Agencies During the Shutdown

\begin{tabular}{|c|c|c|c|}
\hline Agency & Paid & Pct. Furloughed & Total Employees \\
\hline NASA & NO & 97 & 18,250 \\
\hline Housing and Urban Development & NO & 96 & 8,709 \\
\hline Department of Education & NO & 94 & 4,225 \\
\hline Environmental Protection Agency & NO & 94 & 16,205 \\
\hline Securities and Exchange Commission & NO & 94 & 4,149 \\
\hline Corp. for National and Community Service & NO & 88.2 & 610 \\
\hline Department of Commerce & NO & 88 & 46,420 \\
\hline Smithsonian Institution & NO & 84 & 3,514 \\
\hline Department of Labor & NO & 82 & 16,304 \\
\hline Department of Treasury & NO & 82 & 110,000 \\
\hline Department of Interior & NO & 81 & 72,562 \\
\hline Congress and Senate & NO & 75 & 11,629 \\
\hline White House & NO & 74 & 11,701 \\
\hline National Institutes of Health & NO & 73 & 18,646 \\
\hline General Services Administration & NO & 65.4 & 11,821 \\
\hline Small Business Administration & NO & 62 & 3,516 \\
\hline Department of Energy & NO & 61 & 13,814 \\
\hline Health and Human Services & NO & 52 & 78,814 \\
\hline Health Resources and Services Administration & NO & 52 & 40,512 \\
\hline Department of Defense & NO & 50 & 800,000 \\
\hline Food and Drug Administration & NO & 45 & 14,800 \\
\hline Federal Aviation Administration & NO & 33.7 & 46,070 \\
\hline Department of Transportation & NO & 33 & 55,468 \\
\hline Social Security Administration & NO & 28.9 & 62,243 \\
\hline Department of Justice & NO & 19 & 114,486 \\
\hline Department of Homeland Security & NO & 13.5 & 321,117 \\
\hline Department of Agriculture & NO & 8.5 & 100,000 \\
\hline Department of Veterans Affairs & NO & 4 & 332,025 \\
\hline Bonneville Power Administration & YES & 0 & 3,000 \\
\hline Department of State & YES & 0 & 48,900 \\
\hline Federal Reserve Board & YES & 0 & 17,965 \\
\hline US Postal Service & YES & 0 & 626,764 \\
\hline
\end{tabular}

Notes: Calculations are done by the authors. The main source is the Office of Management and Budget Agency Contingency Plans and the Washington Post. Some departments are parts of other agencies. Paid refers to whether or not individuals employed by the department received pay between October 1 and October 25, 2013. Percent furloughed refers to the fraction of workers who were deemed non-essential and kept off the job while the 2013 shutdown was in effect. 
Table 3: Summary Statistics

\begin{tabular}{lcccccc}
\hline \hline & \multicolumn{3}{c}{ State Government Workers } & \multicolumn{3}{c}{ Federal Government Workers } \\
& Mean & Median & Standard Dev. & Mean & Median & Standard Dev. \\
\hline Income (Biweekly) & $2,014.53$ & $1,604.50$ & $1,566.51$ & $2,552.53$ & $2,125.10$ & $1,783.62$ \\
Household Income (Biweekly) & $4,209.51$ & $2,961.99$ & $5,214.78$ & $5,191.84$ & $4,015.74$ & $4,405.05$ \\
Spending (Biweekly) & $3,115.79$ & $2,239.85$ & $3,022.01$ & $3,678.02$ & $2,703.38$ & $3,322.74$ \\
Total Spending (Biweekly) & $4,142.86$ & $2,988.46$ & $3,984.49$ & $4,838.31$ & $3,579.42$ & $4,309.34$ \\
Number of Paychecks (Biweekly) & 1.31 & 1.00 & 0.65 & 1.42 & 1.00 & 0.79 \\
\hline Number of Individuals & \multicolumn{7}{c}{91,650} & & & 61,160 & \\
\hline
\end{tabular}

Notes: All data comes from a large online personal finance website. Income data is derived from direct deposit transfers into checking accounts. Income includes all take home pay in biweekly periods. Transaction spending data is derived from bank, debit, and credit card transactions. Spending does not include durables and ongoing expenditures such as rent and education spending. Total spending includes ongoing expenditures. All dollars values are in 2013 dollars. 
Table 4: The Effect of the Shutdown on Income and Spending

\begin{tabular}{|c|c|c|c|c|c|c|c|c|}
\hline & (1) & (2) & (3) & (4) & (5) & (6) & (7) & (8) \\
\hline & \multicolumn{2}{|c|}{ Income } & \multicolumn{6}{|c|}{ Spending } \\
\hline Government X Shutdown & $\begin{array}{c}-0.234^{* * *} \\
(0.0848)\end{array}$ & $\begin{array}{l}-0.223^{* *} \\
(0.0861)\end{array}$ & $\begin{array}{c}-0.107^{* * *} \\
(0.0357)\end{array}$ & $\begin{array}{l}-0.0706^{*} \\
(0.0408)\end{array}$ & $\begin{array}{c}-0.107^{* * *} \\
(0.0357)\end{array}$ & $\begin{array}{c}-0.0829^{* * *} \\
(0.0104)\end{array}$ & $\begin{array}{c}-0.0432^{* *} \\
(0.0206)\end{array}$ & $\begin{array}{c}-0.0673^{* * *} \\
(0.00661)\end{array}$ \\
\hline
\end{tabular}

Government X Shutdown X Furlough

$-0.0212$

$-0.0759^{*}$

$-0.103^{* *}$

(0.0526)

(0.0444)

$(0.0503)$

\begin{tabular}{|c|c|c|c|c|c|c|c|c|}
\hline Government X Post & & $\begin{array}{l}0.353^{* * *} \\
(0.0639)\end{array}$ & & & $\begin{array}{l}0.113^{* * *} \\
(0.0329)\end{array}$ & & & $\begin{array}{l}0.117^{* * *} \\
(0.0172)\end{array}$ \\
\hline Government X Shutdown & $\begin{array}{c}-832.0^{* * *} \\
(302.5)\end{array}$ & $\begin{array}{c}-783.7^{* *} \\
(312.6)\end{array}$ & $\begin{array}{c}-23.97^{* * *} \\
(7.564)\end{array}$ & $\begin{array}{l}-16.89^{*} \\
(8.662)\end{array}$ & $\begin{array}{c}-23.97^{* * *} \\
(7.564)\end{array}$ & $\begin{array}{c}-36.81^{* * *} \\
(1.844)\end{array}$ & $\begin{array}{c}-24.93^{* * *} \\
(7.075)\end{array}$ & $\begin{array}{c}-36.83^{\text {*** }} \\
(1.842)\end{array}$ \\
\hline
\end{tabular}

Government X Shutdown X Furlough

$-102.0$

(255.0)

$-14.95^{*}$

(8.950)

$-30.82^{*}$

(16.10)

Government X Post

$1516.7^{* * *}$

(257.9)

12.60

(11.00)

6.11 $11^{* * *}$

Unit Fixed Effects

$\begin{array}{cr}\text { Individual } & \text { Individ } \\ \text { Yes } & \text { Yes }\end{array}$

Yes

3,366,464

$3,366,464$

Individual

Individual

Yes

Observations

Yes

Yes

Agency

Yes
Yency

Agency

Agency

Notes: The dependent variable in each specification is log income or the log total amount spent in weekly periods during 2013 . All data comes from a large online personal finance website. Income data is derived from direct deposit transfers into checking accounts. Income includes all take home pay in biweekly periods. Transaction spending data is derived from bank, debit, and credit card transactions. Spending does not include durables and ongoing expenditures such as rent and education spending. Each row shows the the coefficients and standard errors $\beta$ of an interaction between an indicator of whether or not an individual belongs to the treatment group of federal government agencies and a dummy for the 2013 federal government shutdown being in effect, $y_{i t}=$ $\alpha_{t}+\alpha_{i}+\beta \mathbb{1}[t=$ Shutdown $] * \mathbb{1}[\text { FedGov }]_{i t}+\gamma X_{i t}^{\prime}+\epsilon_{i t}$. Columns (2), (4) and (7) include an interaction $\mathbb{1}[t=$ Shutdown $] * \mathbb{1}[\text { FedGov }]_{i t} * \mathbb{1}[\text { Furloughed }]_{i t}$. Columns (2), (5) and (8) include an interaction of federal government workers and the week immediately following the shutdown. The inclusion of agency, individual and time period fixed effects in each specification is denoted below each column. Columns (5)-(8) collapse the data to the agency by week level. All dollars values are in 2013 dollars. Standard errors are clustered at the agency by week level. 
Table 5: The Effect of the Shutdown on Spending by Subcategory

\begin{tabular}{|c|c|c|c|}
\hline & $\begin{array}{c}(1) \\
\text { Restaurants }\end{array}$ & $\begin{array}{c}(2) \\
\text { Fast Food }\end{array}$ & $\begin{array}{c}(3) \\
\text { Groceries }\end{array}$ \\
\hline \multirow[t]{2}{*}{ Government X Shutdown } & $-0.0789^{* *}$ & 0.00893 & 0.0528 \\
\hline & $(0.0349)$ & $(0.0183)$ & $(0.0326)$ \\
\hline \multirow[t]{2}{*}{ Government X Shutdown X Furlough } & -0.0390 & $-0.0779^{* * *}$ & $-0.0612^{* *}$ \\
\hline & $(0.0493)$ & $(0.0241)$ & $(0.0273)$ \\
\hline \multirow[t]{2}{*}{ Observations } & $3,366,464$ & $3,366,464$ & $3,366,464$ \\
\hline & Auto Transport & Public Transport & Gas \\
\hline \multirow[t]{2}{*}{ Government X Shutdown } & 0.0112 & 0.00577 & 0.0295 \\
\hline & $(0.00952)$ & $(0.00516)$ & $(0.0271)$ \\
\hline \multirow[t]{2}{*}{ Government X Shutdown X Furlough } & $-0.0171^{* * *}$ & $-0.0108^{* *}$ & $-0.0758^{* * *}$ \\
\hline & $(0.00561)$ & $(0.00497)$ & $(0.0219)$ \\
\hline \multirow[t]{2}{*}{ Observations } & $3,366,464$ & $3,366,464$ & $3,366,464$ \\
\hline & Check & Shopping & Clothing \\
\hline \multirow[t]{2}{*}{ Government X Shutdown } & $-0.126^{* * *}$ & -0.0191 & $-0.0634^{* *}$ \\
\hline & $(0.0340)$ & $(0.0324)$ & $(0.0267)$ \\
\hline \multirow[t]{2}{*}{ Government X Shutdown X Furlough } & $-0.0696^{*}$ & $-0.0728^{* *}$ & 0.0258 \\
\hline & $(0.0390)$ & $(0.0290)$ & $(0.0312)$ \\
\hline \multirow[t]{2}{*}{ Observations } & $3,366,464$ & $3,366,464$ & $3,366,464$ \\
\hline & Cafes & Amusement & Home Services \\
\hline \multirow[t]{2}{*}{ Government X Shutdown } & $-0.0406^{* * *}$ & $-0.0126^{* * *}$ & 0.00877 \\
\hline & $(0.0122)$ & $(0.00400)$ & $(0.00895)$ \\
\hline \multirow[t]{2}{*}{ Government X Shutdown X Furlough } & 0.0140 & $0.0125^{* * *}$ & $-0.0106^{*}$ \\
\hline & $(0.0117)$ & $(0.00319)$ & $(0.00634)$ \\
\hline \multirow[t]{2}{*}{ Observations } & $3,366,464$ & $3,366,464$ & $3,366,464$ \\
\hline & Kids & Health Insurance & Medical \\
\hline \multirow[t]{2}{*}{ Government X Shutdown } & 0.00463 & 0.00125 & -0.00169 \\
\hline & $(0.00479)$ & $(0.00367)$ & $(0.00299)$ \\
\hline \multirow[t]{2}{*}{ Government X Shutdown X Furlough } & -0.00460 & -0.00427 & 0.000751 \\
\hline & $(0.00414)$ & $(0.00675)$ & $(0.00232)$ \\
\hline \multirow[t]{2}{*}{ Observations } & $3,366,464$ & $3,366,464$ & $3,366,464$ \\
\hline & Auto Payment & Education & Interest Income \\
\hline \multirow[t]{2}{*}{ Government X Shutdown } & 0.0237 & -0.00169 & -0.000597 \\
\hline & $(0.0238)$ & $(0.00299)$ & $(0.00206)$ \\
\hline \multirow[t]{2}{*}{ Government X Shutdown X Furlough } & $-0.0240^{*}$ & 0.000751 & 0.00117 \\
\hline & $(0.0135)$ & $(0.00232)$ & $(0.00144)$ \\
\hline Observations & $3,366,464$ & $3,366,464$ & $3,366,464$ \\
\hline
\end{tabular}

Notes: The dependent variable in each specification is the log total amount spent in specific categories during one week periods during 2013. All data comes from a large online personal finance website. The sample is restricted to the category listed above the coefficients in bold. Transaction spending data is derived from bank, debit, and credit card transactions. Each table shows the coefficients and standard errors $\beta_{1}$ and $\beta_{2}$ from the following specification $y_{i t}=$ $\alpha_{t}+\alpha_{i}+\beta_{1} \mathbb{1}[t=$ Shutdown $] * \mathbb{1}[\text { FedGov }]_{i t}+\beta_{2} \mathbb{1}[t=$ Shutdown $] * \mathbb{1}[\text { FedGov }]_{i t} * \mathbb{1}[\text { Furloughed }]_{i t}+\gamma X_{i t}^{\prime}+$ $\beta_{3} \mathbb{1}[t=$ Shutdown +1$] * \mathbb{1}[\text { FedGov }]_{i t}+\epsilon_{i t}$. The inclusion of agency, individual and time period fixed effects in each specification is denoted below each column. All dollars values are in 2013 dollars. Standard errors are clustered at the agency level by week. 
Table 6: The Effect of the Shutdown on Spending by Subcategory Post-Shutdown

\begin{tabular}{|c|c|c|c|}
\hline & $\begin{array}{c}\text { (1) } \\
\text { Restaurants }\end{array}$ & $\begin{array}{c}(2) \\
\text { Fast Food }\end{array}$ & $\begin{array}{c}(3) \\
\text { Groceries }\end{array}$ \\
\hline \multirow[t]{2}{*}{ Government X Shutdown } & $-0.0789^{* *}$ & 0.00893 & 0.0528 \\
\hline & $(0.0349)$ & $(0.0183)$ & $(0.0326)$ \\
\hline \multirow[t]{2}{*}{ Government X Post } & 0.0535 & 0.00849 & $0.0799^{* * *}$ \\
\hline & $(0.0373)$ & $(0.0285)$ & $(0.0289)$ \\
\hline \multirow[t]{2}{*}{ Observations } & $3,366,464$ & $3,366,464$ & $3,366,464$ \\
\hline & Auto Transport & Public Transport & Gas \\
\hline \multirow[t]{2}{*}{ Government X Shutdown } & 0.0112 & 0.00577 & 0.0295 \\
\hline & $(0.00952)$ & $(0.00516)$ & $(0.0271)$ \\
\hline \multirow[t]{2}{*}{ Government X Post } & 0.00124 & $0.0439^{* * *}$ & -0.0264 \\
\hline & $(0.00696)$ & $(0.0109)$ & $(0.0276)$ \\
\hline \multirow[t]{2}{*}{ Observations } & $3,366,464$ & $3,366,464$ & $3,366,464$ \\
\hline & Check & Shopping & Clothing \\
\hline \multirow[t]{2}{*}{ Government X Shutdown } & $-0.126^{* * *}$ & -0.0191 & $-0.0634^{* *}$ \\
\hline & $(0.0340)$ & $(0.0324)$ & $(0.0267)$ \\
\hline \multirow[t]{2}{*}{ Government X Post } & -0.0139 & $0.124^{* * *}$ & $0.0800^{* *}$ \\
\hline & $(0.0283)$ & $(0.0262)$ & $(0.0370)$ \\
\hline \multirow[t]{2}{*}{ Observations } & $3,366,464$ & $3,366,464$ & $3,366,464$ \\
\hline & Cafes & Amusement & Home Services \\
\hline \multirow[t]{2}{*}{ Government X Shutdown } & $-0.0406^{* * *}$ & $-0.0126^{* * *}$ & 0.00877 \\
\hline & $(0.0122)$ & $(0.00400)$ & $(0.00895)$ \\
\hline \multirow[t]{2}{*}{ Government X Post } & 0.0152 & -0.00574 & $0.0136^{* * *}$ \\
\hline & $(0.0182)$ & $(0.00629)$ & $(0.00435)$ \\
\hline \multirow[t]{2}{*}{ Observations } & $3,366,464$ & $3,366,464$ & $3,366,464$ \\
\hline & Kids & Health Insurance & Medical \\
\hline \multirow[t]{2}{*}{ Government X Shutdown } & 0.00463 & 0.00125 & -0.00825 \\
\hline & $(0.00479)$ & $(0.00367)$ & $(0.00727)$ \\
\hline \multirow[t]{2}{*}{ Government X Post } & 0.00477 & $0.00549^{* * *}$ & 0.00323 \\
\hline & $(0.00682)$ & $(0.00159)$ & $(0.00395)$ \\
\hline \multirow[t]{2}{*}{ Observations } & $3,366,464$ & $3,366,464$ & $3,366,464$ \\
\hline & Auto Payment & Education & Interest Income \\
\hline \multirow[t]{2}{*}{ Government X Shutdown } & 0.0237 & -0.00169 & -0.000597 \\
\hline & $(0.0238)$ & $(0.00299)$ & $(0.00206)$ \\
\hline \multirow[t]{2}{*}{ Government X Post } & $0.0305^{* * *}$ & $0.00926^{* * *}$ & 0.00167 \\
\hline & $(0.0108)$ & $(0.00298)$ & $(0.00212)$ \\
\hline Observations & $3,366,464$ & $3,366,464$ & $3,366,464$ \\
\hline
\end{tabular}

Notes: The dependent variable in each specification is the log total amount spent in specific categories during one week periods during 2013. All data comes from a large online personal finance website. The sample is restricted to the category listed above the coefficients in bold. Transaction spending data is derived from bank, debit, and credit card transactions. Each table shows the coefficients and standard errors $\beta_{1}$ and $\beta_{2}$ from the following specification $y_{i t}=$ $\alpha_{t}+\alpha_{i}+\beta_{1} \mathbb{1}[t=$ Shutdown $] * \mathbb{1}[\text { FedGov }]_{i t}+\beta_{2} \mathbb{1}[t=$ Shutdown $] * \mathbb{1}[\text { FedGov }]_{i t} * \mathbb{1}[\text { PostShutdown }]_{i t}+\gamma X_{i t}^{\prime}+$ $\beta_{3} \mathbb{1}[t=$ Shutdown +1$] * \mathbb{1}[\text { FedGov }]_{i t}+\epsilon_{i t}$. The inclusion of agency, individual and time period fixed effects in each specification is denoted below each column. All dollars values are in 2013 dollars. Standard errors are clustered at the agency level by week. 
Table 7: The Effect of Furloughs on Income and Spending - Daily

\begin{tabular}{|c|c|c|c|c|c|c|}
\hline & $\begin{array}{c}(1) \\
\text { Home }\end{array}$ & $\begin{array}{c}(2) \\
\text { Dining }\end{array}$ & $\begin{array}{c}\text { (3) } \\
\text { Groceries }\end{array}$ & $\begin{array}{c}\text { (4) } \\
\text { Non-Dur. }\end{array}$ & $\begin{array}{c}(5) \\
\text { Services }\end{array}$ & $\begin{array}{c}(6) \\
\text { Home }\end{array}$ \\
\hline Government X Shutdown & $\begin{array}{c}-0.0255 \\
(0.0241)\end{array}$ & $\begin{array}{c}-0.0543^{* * *} \\
(0.00758)\end{array}$ & $\begin{array}{c}0.000233 \\
(0.0122)\end{array}$ & $\begin{array}{c}-0.0269^{*} \\
(0.0155)\end{array}$ & $\begin{array}{c}-0.00737 \\
(0.0147)\end{array}$ & \\
\hline Government X Shutdown X Furlough & $\begin{array}{c}0.143^{* *} \\
(0.0551)\end{array}$ & $\begin{array}{c}-0.0283 \\
(0.0251)\end{array}$ & $\begin{array}{c}0.000728 \\
(0.0236)\end{array}$ & $\begin{array}{c}-0.0329 \\
(0.0385)\end{array}$ & $\begin{array}{c}-0.0502 \\
(0.0353)\end{array}$ & \\
\hline Government X Post Shutdown & $\begin{array}{c}0.0649^{* *} \\
(0.0312)\end{array}$ & $\begin{array}{c}0.0478^{* *} \\
(0.0195)\end{array}$ & $\begin{array}{c}0.0540^{* * *} \\
(0.0111)\end{array}$ & $\begin{array}{l}0.102^{* * *} \\
(0.0129)\end{array}$ & $\begin{array}{c}0.147^{* * *} \\
(0.0330)\end{array}$ & \\
\hline Gov X Post-Shutdown X Fur. & $\begin{array}{c}0.0135 \\
(0.0715)\end{array}$ & $\begin{array}{l}-0.0381 \\
(0.0378)\end{array}$ & $\begin{array}{c}-0.0241^{* * *} \\
(0.00781)\end{array}$ & $\begin{array}{c}0.00653 \\
(0.0147)\end{array}$ & $\begin{array}{c}-0.0204 \\
(0.0708)\end{array}$ & \\
\hline Gov X Period 1 & & & & & & $\begin{array}{c}0.0245 \\
(0.0299)\end{array}$ \\
\hline Gov X Period1 X Fur. & & & & & & $\begin{array}{c}0.0327 \\
(0.0577)\end{array}$ \\
\hline Gov X Period 2 & & & & & & $\begin{array}{c}-0.121^{* * *} \\
(0.0200)\end{array}$ \\
\hline Gov X Period2 X Fur. & & & & & & $\begin{array}{l}0.0591^{*} \\
(0.0348)\end{array}$ \\
\hline Gov X Period3 & & & & & & $\begin{array}{c}-0.0472^{* *} \\
(0.0184)\end{array}$ \\
\hline Gov X Period3 X Fur. & & & & & & $\begin{array}{c}0.0286 \\
(0.0384)\end{array}$ \\
\hline Gov X Period4 & & & & & & $\begin{array}{c}0.0938^{* * *} \\
(0.0224)\end{array}$ \\
\hline Gov X Period4 X Fur. & & & & & & $\begin{array}{c}0.0216 \\
(0.0444)\end{array}$ \\
\hline Agency Fixed Effects & Yes & Yes & Yes & Yes & Yes & Yes \\
\hline Time Effects & Yes & Yes & Yes & Yes & Yes & Yes \\
\hline Observations & 20,721 & 20,721 & 20,721 & 20,721 & 20,721 & 20,721 \\
\hline
\end{tabular}

Notes: The dependent variable in each specification is the log total amount spent in 2013. All data comes from a large online personal finance website. Transaction spending data is derived from bank, debit, and credit card transactions. Each table shows the coefficients and standard errors $\beta_{1}$ and $\beta_{2}$ from the following specification $y_{i t}=\alpha_{t}+\alpha_{i}+\beta_{1} \mathbb{1}[t=$ Shutdown $] *$ $\mathbb{1}[\text { FedGov }]_{i t}+\beta_{2} \mathbb{1}[t=$ Shutdown $] * \mathbb{1}[\text { FedGov }]_{i t} * \mathbb{1}[\text { Furloughed }]_{i t}+\gamma X_{i t}^{\prime}+\epsilon_{i t}$. Column (6) includes additional interactions between being a federal government worker and specific weeks during the shutdown. The inclusion of agency, individual and time period fixed effects in each specification is denoted below each column. All dollars values are in 2013 dollars. Standard errors are clustered at the agency level. 
Table 8: Credit and Shutdown Spending

\begin{tabular}{|c|c|c|c|c|}
\hline & $\begin{array}{c}\text { (1) } \\
\text { Credit Acc. }\end{array}$ & $\begin{array}{c}(2) \\
\text { Opened } \\
\text { Savings Acc. }\end{array}$ & $\begin{array}{c}\text { (3) } \\
\text { Investment Acc. }\end{array}$ & $\begin{array}{c}\text { (4) } \\
\text { Spending }\end{array}$ \\
\hline Federal Gov. Employee & $\begin{array}{l}0.0207^{* * *} \\
(0.00412)\end{array}$ & $\begin{array}{c}0.00267 \\
(0.00404)\end{array}$ & $\begin{array}{c}0.00418 \\
(0.00251)\end{array}$ & \\
\hline Gov. X Shutdown & & & & $\begin{array}{c}-0.0734^{* * *} \\
(0.0054)\end{array}$ \\
\hline Opened Credit Acc. & & & & $\begin{array}{l}0.0281^{* * *} \\
(0.00854)\end{array}$ \\
\hline Had Credit Acc. & & & & $\begin{array}{l}0.0471^{* *} \\
(0.0219)\end{array}$ \\
\hline Time Period & - & - & - & $\mathrm{FE}$ \\
\hline Fixed Effects & - & - & - & Individual \\
\hline Observations & 148,833 & 148,833 & 148,833 & $3,366,464$ \\
\hline
\end{tabular}

Notes: The dependent variable in each specification is listed in the column above each specification. All data comes from a large online personal finance website. Transaction spending and account data is derived from bank, debit, and credit card transactions. The inclusion of agency, individual and time period fixed effects in each specification is denoted below each column. All dollars values are in 2013 dollars. The opened and had credit account denote an interaction between having and opening credit accounts during the shutdown. Column 4 shows a specification analogous to the individual results in table 4. Standard errors are clustered at the agency level. 


\section{A Unobserved Credit}

This section examines the mechanism for the observed spending decreases, and specifically examines whether the observed drop in spending was due to a real drop in spending or the shutdown causing individuals to switch to unobserved accounts. For example, it is possible that some individuals affected by the shutdown could have open and borrowed on credit cards that were not linked to the online personal finance website. Credit card spending is observed in the data, and if this were indeed the case we would see an increase in credit card payments following the shutdown for individuals who reduced observed spending during the shutdown. To explore this possibility, we run the following specification:

$$
\begin{aligned}
& \text { Credit }_{i t}=\alpha_{t}+\alpha_{a}+\beta_{1} \mathbb{1}[t=\text { PostShutdown }] * \mathbb{1}[t=\text { FedGov }] \\
& +\beta_{2} \mathbb{1}[t=\text { PostShutdown }] * \mathbb{1}[t=\text { FedGov }] * \frac{\text { ShutdownSpending }}{\text { AverageSpending }_{i}}+\nu_{i t}
\end{aligned}
$$

Where $\alpha_{a}$ are agency fixed effects and $\frac{\text { ShutdownSpending }}{\text { AverageSpending }}{ }_{i}$ is the ratio of spending during the shutdown to average spending. If individuals are borrowing on unlinked accounts, then there should be an larger increase in credit card payments following the shutdown for individual who cut observed consumption to a greater degree during the shutdown and the coefficient $\beta_{2}$ will be negative. 
Figure A1: Spending Difference by Additional Categories Effect of Shutdown

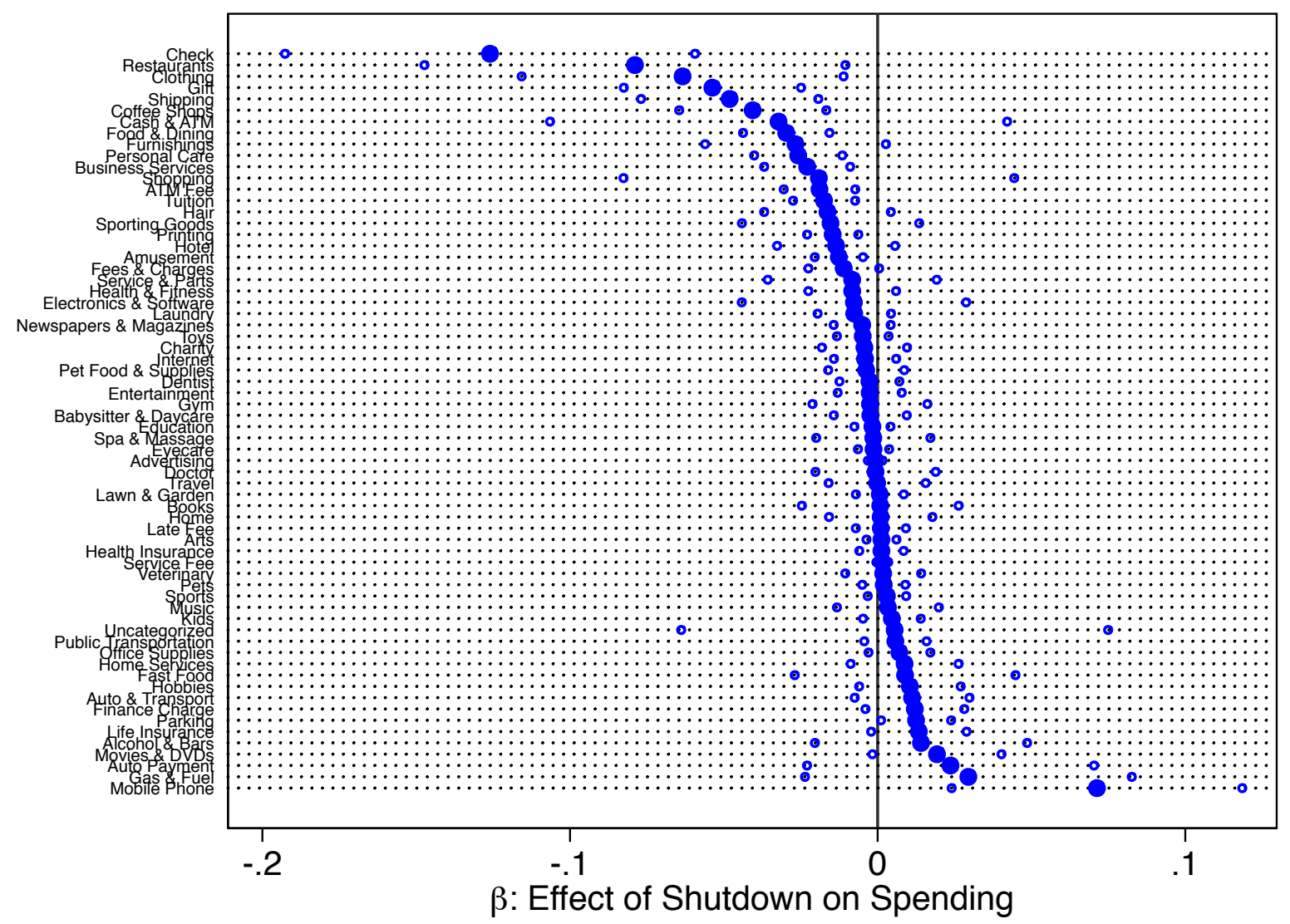

Notes: The figure on the left plots the coefficients $\beta_{1}$ of interactions between indicators of whether or not an individual belongs to the treatment group of federal government areas and time period dummies from the specification $y_{i t}=\alpha_{t}+\alpha_{i}+\beta_{1} \mathbb{1}[t=$ Shutdown $] * \mathbb{1}[\text { FedGov }]_{i t}+\beta_{2} \mathbb{1}[t=S h u t d o w n] * \mathbb{1}[\text { FedGov }]_{i t} *$ $\mathbb{1}[\text { Furloughed }]_{i t}+\gamma X_{i t}^{\prime}+\epsilon_{i t}$. The specification include individual and time period fixed effects. The dependent variable in each specification is the log total amount spent in a specific category during one week periods during the second six months of 2013. The category is listed to the left of each coefficient. The solid circles show the relative point estimates labeled above each panel. The hollow circles show a 95\% confidence interval. Categories are sorted by magnitudes, with the largest negative effect, at the top and the largest positive effect, at the bottom. Standard errors are clustered at the agency level. 
Figure A2: Spending Difference by Additional Categories

Effect of Furlough

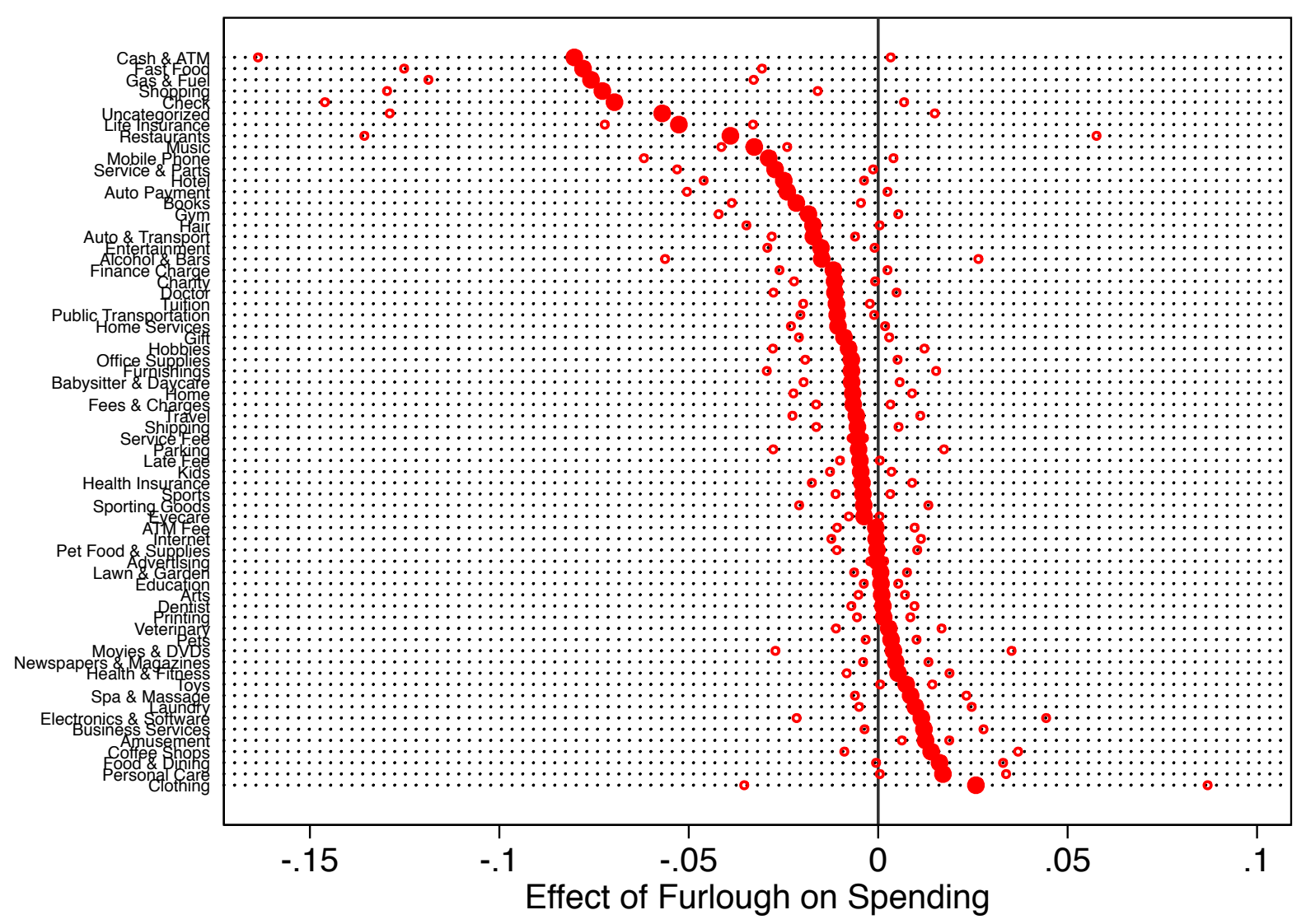

Notes: The figure on the left plots the coefficients $\beta_{2}$ of interactions between indicators of whether or not an individual belongs to the treatment group of federal government areas and time period dummies, while the figure on the left sows and probability of being furloughed from the specification $y_{i t}=$ $\alpha_{t}+\alpha_{i}+\beta_{1} \mathbb{1}[t=$ Shutdown $] * \mathbb{1}[\text { FedGov }]_{i t}+\beta_{2} \mathbb{1}[t=$ Shutdown $] * \mathbb{1}[\text { FedGov }]_{i t} * \mathbb{1}[\text { Furloughed }]_{i t}+\gamma X_{i t}^{\prime}+\epsilon_{i t}$. The specification include individual and time period fixed effects. The dependent variable in each specification is the log total amount spent in a specific category during one week periods during the second six months of 2013. The category is listed to the left of each coefficient. The solid circles show the relative point estimates labeled above each panel. The hollow circles show a 95\% confidence interval. Categories are sorted by magnitudes, with the largest negative effect, at the top and the largest positive effect, at the bottom. Standard errors are clustered at the agency level. 
Figure A3: Spending Difference by Additional Categories Effect of Shutdown

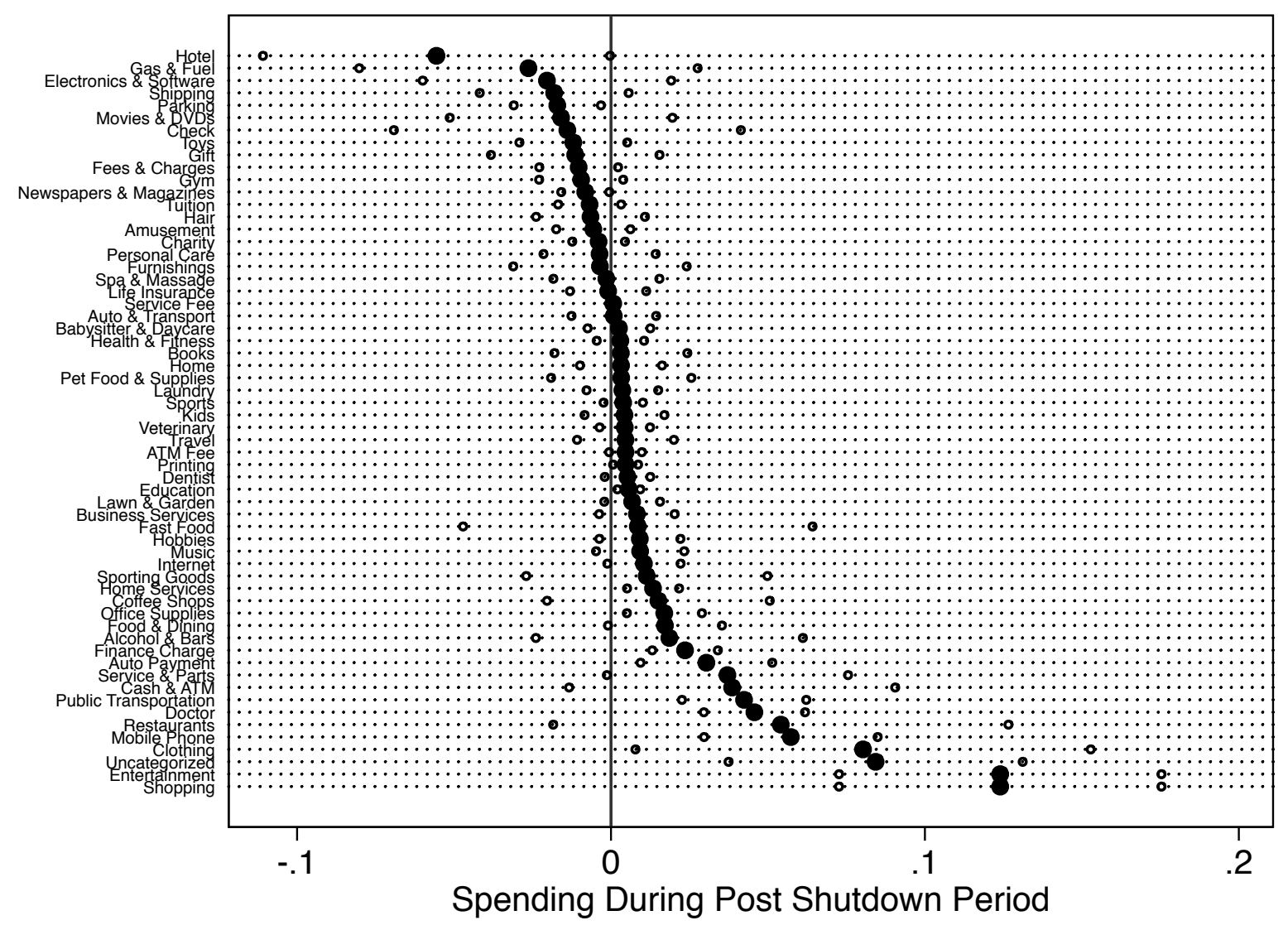

Notes: The figure on the left plots the coefficients $\beta_{1}$ of interactions between indicators of whether or not an individual belongs to the treatment group of federal government areas and time period dummies from the specification $y_{i t}=\alpha_{t}+\alpha_{i}+\beta_{1} \mathbb{1}[t=$ Shutdown $] * \mathbb{1}[\text { FedGov }]_{i t}+\beta_{2} \mathbb{1}[t=$ Shutdown $] * \mathbb{1}[\text { FedGov }]_{i t} *$ $\mathbb{1}[\text { Post }]_{i t}+\gamma X_{i t}^{\prime}+\epsilon_{i t}$. The specification include individual and time period fixed effects. The dependent variable in each specification is the log total amount spent in a specific category during one week periods during the second six months of 2013. The category is listed to the left of each coefficient. The solid circles show the relative point estimates labeled above each panel. The hollow circles show a 95\% confidence interval. Categories are sorted by magnitudes, with the largest negative effect, at the top and the largest positive effect, at the bottom. Standard errors are clustered at the agency level. 
Figure A4: State and Federal Government Workers During the Shutdown

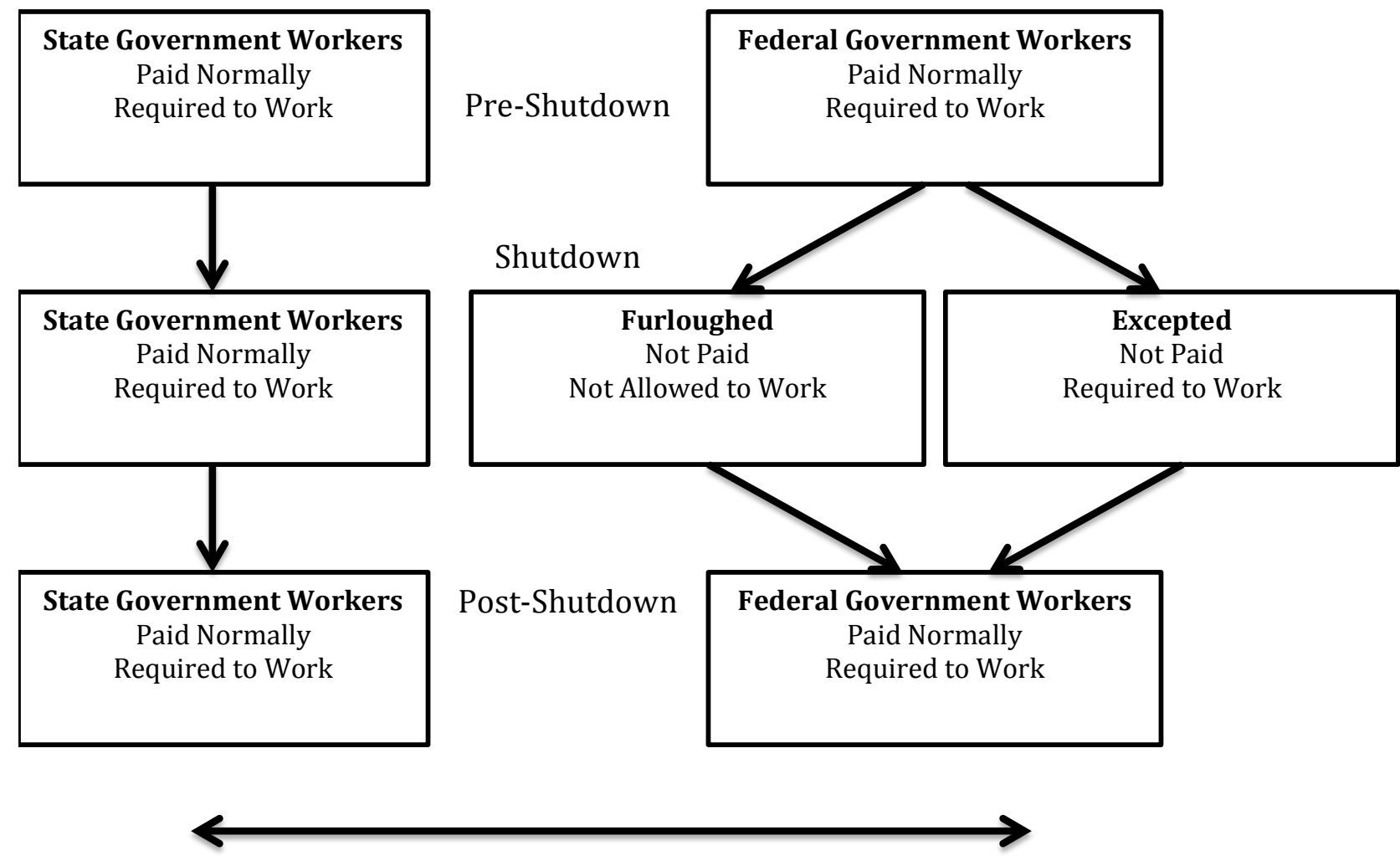

Difference between state and federal government workers gives the effect of changes in income and time allocation on consumption

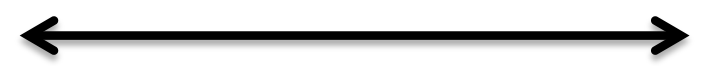

Difference between furloughed and excepted federal government workers gives the differential effect of time allocation on consumption

Notes: This figure shows income and time allocation effects for state and federal government workers before, during and after the shutdown. The category of worker, state or federal, and excepted or furloughed, is listed in bold at the top of each box. Whether or not they are being paid during the time period is listed first in plain text, and then whether or not they were required to work follows. The time period, pre-shutdown, during the shutdown, or post-shutdown is listed in the center of the diagram. 
Table A1: Placebo Tests on Demographics

\begin{tabular}{|c|c|c|c|c|}
\hline & (1) & $(2)$ & (3) & $(4)$ \\
\hline \multirow[b]{2}{*}{ Government X Shutdown } & \multicolumn{4}{|c|}{ Female } \\
\hline & $\begin{array}{c}0.00114 \\
(0.00543)\end{array}$ & $\begin{array}{c}0.00319 \\
(0.00281)\end{array}$ & $\begin{array}{c}0.00177 \\
(0.00331)\end{array}$ & $\begin{array}{c}0.00249 \\
(0.00292)\end{array}$ \\
\hline \multirow[b]{2}{*}{ Government X Shutdown } & \multicolumn{4}{|c|}{$\begin{array}{c}\text { College } \\
\end{array}$} \\
\hline & $\begin{array}{c}-0.00348 \\
(0.0123)\end{array}$ & $\begin{array}{c}0.00480 \\
(0.00321)\end{array}$ & $\begin{array}{c}0.00474 \\
(0.00318)\end{array}$ & $\begin{array}{l}0.00548^{*} \\
(0.00272)\end{array}$ \\
\hline \multirow[b]{2}{*}{ Government X Shutdown } & \multicolumn{4}{|c|}{ Graduate Degree } \\
\hline & $\begin{array}{c}-0.00175 \\
(0.00302) \\
\end{array}$ & $\begin{array}{c}-0.00192 \\
(0.00137)\end{array}$ & $\begin{array}{c}-0.00202 \\
(0.00214)\end{array}$ & $\begin{array}{c}-0.00202 \\
(0.00217)\end{array}$ \\
\hline \multirow[b]{2}{*}{ Government X Shutdown } & \multicolumn{4}{|c|}{ PhD } \\
\hline & $\begin{array}{c}0.000210 \\
(0.000934)\end{array}$ & $\begin{array}{l}0.000690^{*} \\
(0.000376)\end{array}$ & $\begin{array}{l}-0.000315 \\
(0.000813)\end{array}$ & $\begin{array}{c}-0.000298 \\
(0.000817)\end{array}$ \\
\hline \multirow[b]{2}{*}{ Government X Shutdown } & \multicolumn{4}{|c|}{ Owns Home } \\
\hline & $\begin{array}{l}0.00703^{*} \\
(0.00363)\end{array}$ & $\begin{array}{c}0.00416 \\
(0.00390)\end{array}$ & $\begin{array}{c}0.00389 \\
(0.00413)\end{array}$ & $\begin{array}{c}0.00390 \\
(0.00414)\end{array}$ \\
\hline \multirow[b]{2}{*}{ Government X Shutdown } & \multicolumn{4}{|c|}{ Married } \\
\hline & $\begin{array}{r}-0.000785 \\
(0.00403)\end{array}$ & $\begin{array}{l}-0.00490 \\
(0.00307)\end{array}$ & $\begin{array}{c}-0.00423 \\
(0.00364)\end{array}$ & $\begin{array}{l}-0.00437 \\
(0.00356)\end{array}$ \\
\hline \multirow[b]{2}{*}{ Government X Shutdown } & \multicolumn{4}{|c|}{ Individuals in Household } \\
\hline & $\begin{array}{r}-0.00517 \\
(0.0317) \\
\end{array}$ & $\begin{array}{c}0.0119 \\
(0.0118)\end{array}$ & $\begin{array}{c}0.0109 \\
(0.0131) \\
\end{array}$ & $\begin{array}{c}0.0115 \\
(0.0132) \\
\end{array}$ \\
\hline & \multicolumn{4}{|c|}{$\begin{array}{l}\text { Children } \\
\end{array}$} \\
\hline Government X Shutdown & $\begin{array}{c}-0.00200 \\
(0.0185)\end{array}$ & $\begin{array}{l}-0.00915 \\
(0.0181)\end{array}$ & $\begin{array}{c}-0.0237 \\
(0.0209)\end{array}$ & $\begin{array}{l}-0.0246 \\
(0.0207)\end{array}$ \\
\hline Observations & 136,505 & 136,505 & 136,505 & 136,505 \\
\hline Time Period & FE & $\mathrm{FE}$ & FE & $\mathrm{FE}$ \\
\hline Fixed Effects & Government & Agency & Agency & Agency X Week \\
\hline
\end{tabular}

Notes: The dependent variable in each specification is listed above the specification in bold. All data comes from a large online personal finance website. Demographics were voluntarily reported by some individuals. Each table shows the coefficients and standard errors $\beta_{1}$ from the following specification $y_{i t}=\alpha_{t}+\alpha_{i}+\beta_{1} \mathbb{1}[t=$ Shutdown $] * \mathbb{1}[\text { FedGov }]_{i t}+$ $\gamma X_{i t}^{\prime}+\epsilon_{i t}$. The inclusion of agency, individual and time period fixed effects in each specification is denoted below each column. Standard errors are clustered at the agency level. 
Table A2: The Effect of the Shutdown on Spending by Category

\begin{tabular}{|c|c|c|c|}
\hline & (1) & (2) & (3) \\
\hline & \multicolumn{3}{|c|}{ Ln(Spending) } \\
\hline & \multicolumn{3}{|c|}{ Dining Out } \\
\hline Government X Shutdown & $\begin{array}{c}-0.0986^{* * *} \\
(0.0288)\end{array}$ & $\begin{array}{l}-0.0597^{*} \\
(0.0312)\end{array}$ & $\begin{array}{c}-0.0986^{* * *} \\
(0.0288)\end{array}$ \\
\hline Government X Shutdown X Furlough & & $\begin{array}{l}-0.0820^{*} \\
(0.0446)\end{array}$ & \\
\hline Government X Post & & & $\begin{array}{l}0.0689^{* *} \\
(0.0337) \\
\end{array}$ \\
\hline & \multicolumn{3}{|c|}{ Groceries } \\
\hline Government X Shutdown & $\begin{array}{l}-0.00432 \\
(0.0202)\end{array}$ & $\begin{array}{c}-0.000434 \\
(0.0214)\end{array}$ & $\begin{array}{l}-0.00432 \\
(0.0202)\end{array}$ \\
\hline Government X Shutdown X Furlough & & $\begin{array}{l}-0.00818 \\
(0.0147)\end{array}$ & \\
\hline Government X Post & & & $\begin{array}{c}0.0379 \\
(0.0266) \\
\end{array}$ \\
\hline & \multicolumn{3}{|c|}{ Non-Durables } \\
\hline Government X Shutdown & $\begin{array}{c}-0.0752^{* * *} \\
(0.0206)\end{array}$ & $\begin{array}{l}-0.0412 \\
(0.0310)\end{array}$ & $\begin{array}{c}-0.0752^{* * *} \\
(0.0206)\end{array}$ \\
\hline Government X Shutdown X Furlough & & $\begin{array}{l}-0.0715 \\
(0.0480)\end{array}$ & \\
\hline Government X Post & & & $\begin{array}{l}0.111^{* * *} \\
(0.0226) \\
\end{array}$ \\
\hline & \multicolumn{3}{|c|}{ Durables } \\
\hline Government X Shutdown & $\begin{array}{l}-0.0254 \\
(0.0273)\end{array}$ & $\begin{array}{l}-0.00223 \\
(0.0373)\end{array}$ & $\begin{array}{l}-0.0254 \\
(0.0273)\end{array}$ \\
\hline Government X Shutdown X Furlough & & $\begin{array}{l}-0.0488 \\
(0.0431)\end{array}$ & \\
\hline Government X Post & & & $\begin{array}{c}0.0810^{* * *} \\
(0.0272)\end{array}$ \\
\hline & \multicolumn{3}{|c|}{ Cash \& Check } \\
\hline Government X Shutdown & $\begin{array}{l}-0.133^{* * *} \\
(0.0344)\end{array}$ & $\begin{array}{l}-0.1000^{*} \\
(0.0517)\end{array}$ & $\begin{array}{c}-0.133^{* * *} \\
(0.0344)\end{array}$ \\
\hline Government X Shutdown X Furlough & & $\begin{array}{l}-0.0704 \\
(0.0709)\end{array}$ & \\
\hline Government X Post & & & $\begin{array}{l}0.113^{* * *} \\
(0.0334)\end{array}$ \\
\hline & & Health & \\
\hline Government X Shutdown & $\begin{array}{c}0.00159 \\
(0.00358)\end{array}$ & $\begin{array}{c}0.00507 \\
(0.00365)\end{array}$ & $\begin{array}{c}0.00159 \\
(0.00358)\end{array}$ \\
\hline Government X Shutdown X Furlough & & $\begin{array}{l}-0.00735 \\
(0.00468)\end{array}$ & \\
\hline Government X Post & & & $\begin{array}{c}0.00569 \\
(0.00350)\end{array}$ \\
\hline $\begin{array}{l}\text { Time Period } \\
\text { Fixed Effects }\end{array}$ & $\begin{array}{c}\mathrm{FE} \\
\text { Individual }\end{array}$ & $\begin{array}{c}\mathrm{FE} \\
\text { Individual }\end{array}$ & $\begin{array}{c}\mathrm{FE} \\
\text { Individual }\end{array}$ \\
\hline
\end{tabular}

Notes: The dependent variable in each specification is the log total amount spent in two week periods during 2013. All data comes from a large online personal finance weB $\$$ te. The sample is restricted to the category listed above the coefficients in bold. Transaction spending data is derived from bank, debit, and credit card transactions. Each table shows the coefficients and standard errors $\beta_{1}$ and $\beta_{2}$ from the following specification $y_{i t}=\alpha_{t}+\alpha_{i}+\beta_{1} \mathbb{1}[t=S h u t d o w n] *$ $\mathbb{1}[\text { FedGov }]_{i t}+\beta_{2} \mathbb{1}[t=$ Shutdown $] * \mathbb{1}[\text { FedGov }]_{i t} * \mathbb{1}[\text { Furloughed }]_{i t}+\gamma X_{i t}^{\prime}+\epsilon_{i t}$. The inclusion of agency, individual and time period fixed effects in each specification is denoted below each column. Standard errors are clustered at the agency level. 
Table A3: Saving and Credit Constraints

\begin{tabular}{lcccc}
\hline \hline & $(1)$ & $(2)$ & $(3)$ & $(4)$ \\
& & \multicolumn{3}{c}{ Lovels } \\
& & \multicolumn{4}{c}{ Panel A: Savings } \\
\hline Pre-Shutdown & -0.0596 & -0.0595 & -110.5 & -110.3 \\
& $(0.0825)$ & $(0.0861)$ & $(193.2)$ & $(201.8)$ \\
\hline Observations & 249,950 & 249,950 & 249,950 & 249,950 \\
\hline \multirow{3}{*}{ Government X Shutdown } & $-0.0197^{*}$ & $-0.0333^{* * *}$ & $-92.05^{* * *}$ & $-110.6^{* * *}$ \\
& $(0.0100)$ & $(0.0114)$ & $(31.51)$ & $(38.37)$ \\
Government X Shutdown X Savings & $0.00163^{* * *}$ & $0.000457^{* *}$ & $3.919^{* *}$ & $1.789^{*}$ \\
& $(0.000442)$ & $(0.000181)$ & $(1.796)$ & $(1.032)$ \\
Savings & $-0.00286^{* * *}$ & & $-10.59^{* * *}$ & \\
& $(0.000377)$ & & $(1.208)$ & \\
\hline Observations & 449,980 & 449,980 & 449,980 & 449,980 \\
\hline Time Period & FE & FE & FE & FE \\
Fixed Effects & Agency X Week & Individual & Agency X Week & Individual \\
\hline \hline
\end{tabular}

Notes: In the top panel, savings are defined as income minus transactions in each monthly period. In the bottom panel savings are defined as the sum of all income minus transactions in the nine months prior to the shutdown, in thousands of dollars. The dependent variable in the top panel is savings. The dependent variable in the bottom panel is spending. The dependent variable in each specification is the log total amount spent in two week periods during 2013. All data comes from a large online personal finance website. Transaction spending data is derived from bank, debit, and credit card transactions. The inclusion of agency, individual and time period fixed effects in each specification is denoted below each column. Standard errors are clustered at the agency level. 
Table A4: Heterogeneous Effects of Shutdown

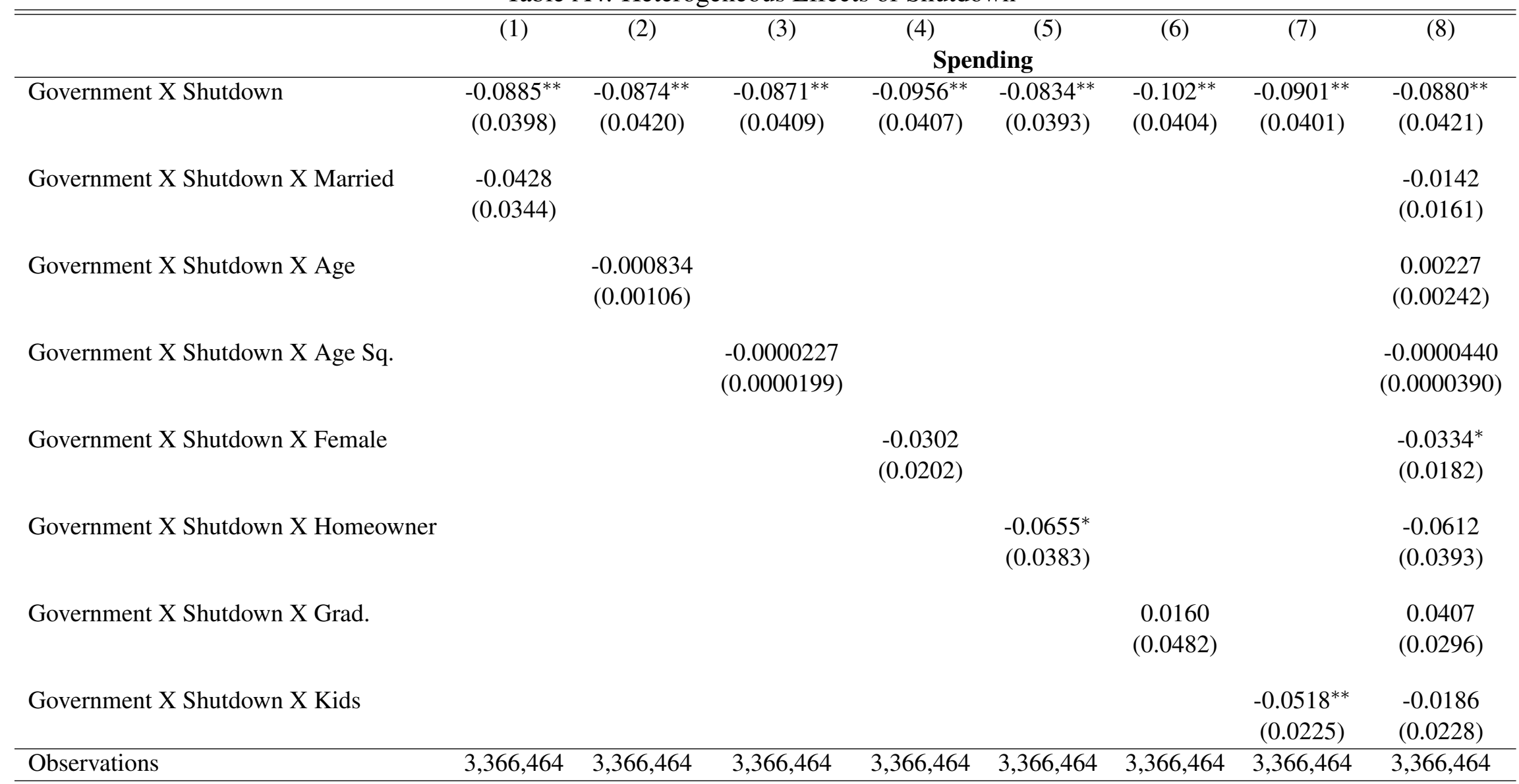

Notes: The dependent variable in each specification is the log total amount spent during one week periods during 2013. All data comes from a large online personal finance website. Transaction spending data is derived from bank, debit, and credit card transactions. Demographics are self reported on the online platform. Members denotes the number of individuals, adult and children, living in a household. Kids is an indicator of whether or not a household has children. Grad is an indicator of whether or not an individual has a masters or doctorate degree. Each table shows the coefficients and standard errors $\beta_{1}$ and $\beta_{2}$ from the following specification $y_{i t}=\alpha_{t}+\alpha_{i}+\beta_{1} \mathbb{1}[t=$ Shutdown $] * \mathbb{1}\left[\right.$ FedGov $_{i t}+\beta_{2} \mathbb{1}\left[t=\right.$ Shutdown $_{*} * \mathbb{1}\left[\right.$ FedGov $_{i t} * X_{i}+\beta_{3} \mathbb{1}[t=$ Shutdown +1$] * \mathbb{1}\left[F_{\text {ed }} \text { Gov }\right]_{i t}+\epsilon_{i t}$ where $X_{i}$ denotes demographic characteristics noted in each row. The inclusion of individual and time period fixed effects in each specification is denoted below each column. All dollars values are in 2013 dollars. Standard errors are clustered at the agency by week level. 
Table A5: The Effect of the Shutdown on Spending by Subcategory- Not Winsorized

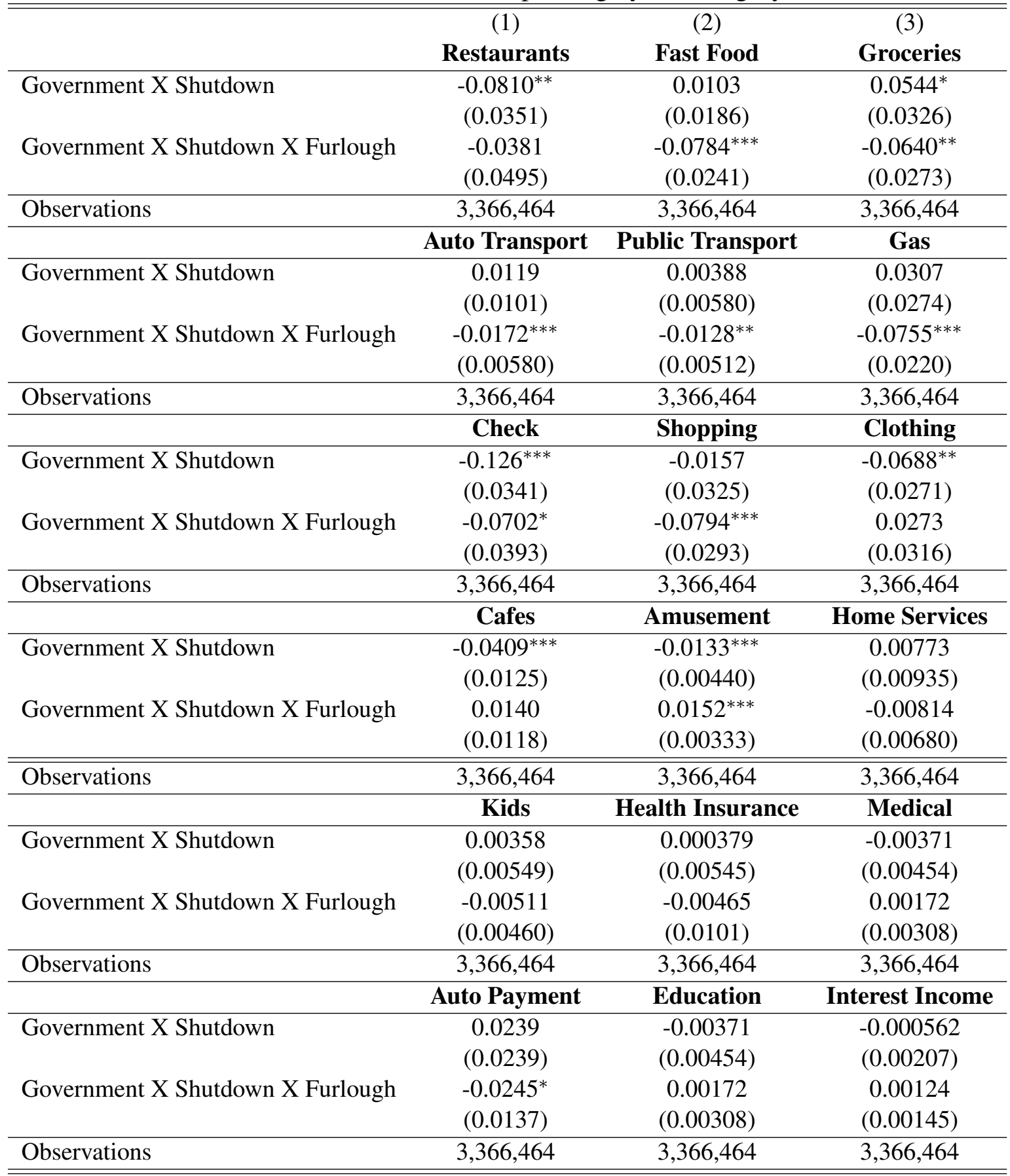

Notes: The dependent variable in each specification is the log total amount spent in specific categories during one week periods during 2013. All data comes from a large online personal finance website. The sample is restricted to the category listed above the coefficients in bold. Transaction spending data is derived from bank, debit, and credit card transactions. Each table shows the coefficients and standard errors $\beta_{1}$ and $\beta_{2}$ from the following specification $y_{i t}=$ $\alpha_{t}+\alpha_{i}+\beta_{1} \mathbb{1}[t=$ Shutdown $] * \mathbb{1}[\text { FedGov }]_{i t}+\beta_{2} \mathbb{1}[t=$ Shutdown $] * \mathbb{1}[\text { FedGov }]_{i t} * \mathbb{1}[\text { Furloughed }]_{i t}+\gamma X_{i t}^{\prime}+$ $\beta_{3} \mathbb{1}[t=$ Shutdown +1$] * \mathbb{1}[\text { FedGov }]_{i t}+\epsilon_{i t}$. The inclusion of agency, individual and time period fixed effects in each specification is denoted below each column. All dollars values are in 2013 dollars. Standard errors are clustered at the agency level by week. 